\title{
Over het hek van de dam bij 'derdenschade'
}

\author{
Esther Engelhard ${ }^{1}$
}

\section{Inleiding}

\section{I.I Centrale stelling}

Bij een verkeersongeval is Brigitte ernstig gewond geraakt. Dit heeft grote gevolgen, ook voor haar partner Chris: hij neemt de dagelijkse verzorging van Brigitte en hun huishouden op zich. Chris gaat zwaar gebukt onder de ingrijpende veranderingen die dit ook voor zijn leven betekent. Hij is een zelfstandig gevestigd psycholoog en ziet zich hierdoor genoodzaakt zijn spreekuur tijdelijk te bekorten. Als gevolg daarvan derft hij inkomsten. Hij wil deze schade vergoed zien van Anton, die het ongeval heeft veroorzaakt.

Dit is een voorbeeld van 'derdenschade' in het personenschaderecht. Daar gaan de laatste jaren stemmen op voor een fundamentele bezinning op de verhaalspositie van derden. ${ }^{2}$ Derdenschade staat ook op andere deelterreinen van het Nederlandse aansprakelijkheids- en schadevergoedingsrecht in de belangstelling. Onduidelijkheid heerst bijvoorbeeld voor wat betreft de verhaalspositie van aandeelhouders en van schuldeisers met afgeleide schade. ${ }^{3}$

Al deze deelterreinen worden vaak afzonderlijk in de literatuur aan de orde gesteld, ${ }^{4}$ maar wat opvalt, is dat de nadruk over de gehele linie ligt op de bijzondere beperkingen waar vorderingen van derden aan worden onderworpen. Dat is op

I Esther Engelhard is universitair hoofddocent aan het Molengraaff Instituut voor Privaatrecht, Universiteit Utrecht, E.Engelhard@uu.nl. Dit onderzoek werd in Gent verricht in het kader van een onderzoeksverblijf waarvoor ik prof. dr. H. Bocken en prof. dr. I. Boone zeer erkentelijk ben. Hiervoor dank ik ook de Universiteit Gent en het Molengraaff Instituut voor Privaatrecht van de Universiteit Utrecht.

2 S.D. Lindenbergh, 'Derdenschade', TVP 2006, p. 97; R. Rijnhout, 'Wetsvoorstel affectieschade verworpen door de Eerste Kamer', TVP 20I0, p. 37-4I; E.F.D. Engelhard \& I. Giesen, 'Compensation for the Loss of Housekeeping', in: Loss of Housekeeping Capacity, E. Karner/K. Oliphant (Eds.), Wien/New York: Springer, 2010 (nog te verschijnen); Kamerstukken I, 2009-Io, 28 78I, 23 maart 2010.

3 J.W.H. van Wijk, 'Afgeleide schade', TOP 2008, p. 25-33, p. 3 I-32 en M.J. Rutgers, Het recht van de aandeelhouder bij afgeleide schade, Tilburg: Celsus, 2010, p. 68.

4 Doch zie T. Hartlief, 'Wie heeft er recht op vergoeding van personenschade? Enkele opmerkingen over afbakening van de kring van gerechtigden in het aansprakelijkheids- en schadevergoedingsrecht', TVP 2006, p. 98-I04, die voor derdenschade bij personenschade ook wijst op ontwikkelingen buiten dat terrein. 
zichzelf niet vreemd: die beperkingen maken de verhaalspositie van derden immers minder gunstig dan die van de primair benadeelde. Maar tegelijk vormen die bijzondere beperkingen de basis waarop vergoeding mogelijk is. Dit heeft iets tegenstrijdigs: aan de beperking van de verhaalsmogelijkheden van derden ligt tevens de erkenning en uitbreiding van die mogelijkheden ten grondslag. Waarop berust die uitbreiding? Dat is de kernvraag van dit preadvies. Ik zoek het antwoord echter niet op één deelterrein in het bijzonder, ${ }^{5}$ maar kies voor een wat bredere en fundamentele benadering van het thema derdenschade.

Het spanningsveld dat ik zojuist aanstipte, en hier centraal zal stellen, biedt ook een aardige insteek voor de vergelijking die ter vergadering zal worden gemaakt tussen het Nederlandse en Belgische recht ten aanzien van derdenschade, ook overigens in het licht van 'Europese' keuzes op dit punt van de Draft Common Frame of Reference en die in het preadvies van I. Boone en B. Wylleman zullen worden behandeld. De meest in het oog springende verschillen tussen de twee landen betreffen de relativiteitsleer en de normatieve causaliteitstoets (en het ontbreken van die beide technieken in het Belgische recht). Dit roept evidente vragen op, zoals: betekenen deze (op het oog slechts formele) verschillen dat ook de resultaten in beide landen anders zijn, bijvoorbeeld in die zin dat bepaalde typen derdenschade in het ene land niet en in het andere wel verhaalbaar zijn? En indien dat zo is, ontstaat de vraag wat daar de redenen van zijn en welke uitzonderingen worden toegestaan, en vooral de vraag wat beide landen van elkaar kunnen leren. In dit preadvies zal mede met het oog hierop het Nederlandse recht worden besproken.

Maar ook voor de landenvergelijking wil ik fundamenteler insteken: hoe belangrijk zijn die verschillen als beide rechtsstelsels wél dezelfde vormen van derdenschade onderkennen en er in beide landen gediscussieerd wordt om die te vergoeden? Is juist met de introductie van technieken en beperkingen, ook als die verschillend zijn, eigenlijk niet vooral het gemeenschappelijke punt van de (mogelijke) uitbreiding van de verhaalsmogelijkheden gegeven?

\section{I.2 Systematisering 'derdenschade': drie categorieën}

Het centrale thema 'derdenschade' doet nog het meest denken aan omvallende dominostenen: A veroorzaakt schade aan $\mathrm{B}$ en dáárdoor lijden $\mathrm{C}$ en eventuele verdere schakels (D, E, enzovoort) schade. Er is geen vastomlijnde definitie, maar ik zou derdenschade willen definiëren als: schade die is veroorzaakt door andermans schade. Doordat de schade in verschillende handen valt, zijn er minstens twee sequentiële oorzaken in feitelijke zin: ${ }^{6}$ Brigitte raakt ernstig gewond en dat heeft vervolgens consequenties voor het welzijn en de vermogenssituatie van de personen en organisaties

5 Door Rianka Rijnhout, tevens verbonden aan het Molengraaff Instituut voor Privaatrecht, wordt momenteel een rechtsvergelijkend promotieonderzoek verricht naar de kring van gerechtigden bij letsel en overlijden.

6 In juridische zin zal ik er in dit preadvies van uitgaan dat er maar één veroorzaker is, namelijk degene die aansprakelijk is voor het veroorzaken van de initiële schade (van de primair benadeelde). 
waarmee zij in verband staat, zoals haar partner Chris, maar ook opdrachtgevers, enzovoort. Dat roept de vraag op of de vergoedingsplicht van de aansprakelijke zich ook naar die schade uitstrekt en of Chris (of andere derden) daarvoor dan een zelfstandig vorderingsrecht heeft. Ook is een vraag wie dan het vorderingsrecht (en de actie) toekomt: Chris zelf of Brigitte, als primair benadeelde (die dan het bedrag van de derdenschade op haar beurt aan Chris zou moeten voldoen)?

Die vragen krijgen een ‘scherper randje’ naarmate de schade typisch op zo'n indirecte wijze tot stand komt. Overlijdensschade is in dit opzicht exemplarisch: als de fout van Anton het overlijden van Brigitte tot gevolg heeft, dan treft dit indirect ook haar nabestaanden. Maar er zijn ook andere gevallen waarin schade typisch indirect tot stand komt. Volgens mij laten deze gevallen zich systematiseren op de grond dat de derde in een bijzondere relatie staat tot de persoon, zaken en/of het vermogen van de primair benadeelde. Daarbij onderscheid ik drie categorieën derdenschade:

- De eerste categorie derdenschade betreft de persoon van de primair benadeelde. Het gaat dan met name om schade van derden die verband houdt met geestelijk of lichamelijk letsel en/of overlijden van de primair benadeelde, zoals in het genoemde voorbeeld. Te denken valt aan naasten (zoals Chris), maar ook aan particuliere en sociale schadedragers die uitkeringen verschuldigd zijn, ${ }^{7}$ of aan werkgevers die gedurende de arbeidsongeschiktheid het loon moeten doorbetalen en ook bedrijfsschade kunnen lijden doordat de primair benadeelde (tijdelijk) onvervangbaar is. Naar geldend recht hebben deze derden voor de meeste van deze schadeposten een wettelijk beperkt verhaalsrecht jegens de schadeveroorzaker. ${ }^{8}$

Een ander type derdenschade dat onder deze categorie kan vallen is de derdenschade door inbreuken op persoonlijkheidsrechten van de primair benadeelde. Denk aan de negatieve gevolgen die de verspreiding van onjuiste informatie over iemands (vroegere) privéleven kan hebben voor zijn naasten. Tenzij de getroffen naasten ook een eigen geschonden recht kunnen inroepen (bijvoorbeeld hun recht op privacy offamily life), zijn hun verhaalsmogelijkheden jegens de inbreukmaker hier zeer beperkt.

- De tweede categorie derdenschade betreft zaakgerelateerde derdenschade: A is aansprakelijk voor de beschadiging van een zaak die in eigendom is van B, maar naast (of in plaats van) B ondervinden (ook) derden hiervan schade. Dat kunnen omwonenden zijn of medeweggebruikers, ${ }^{9}$ maar het kunnen ook derden zijn die bijzondere belangen bij de zaak hebben. Denk bijvoorbeeld aan schadeverzekeraars, kopers, huurders of pachters van de zaak en beperkt gerechtigden, treinreizigers, stroomafnemers en internetgebruikers (die bijvoorbeeld schade ondervinden van de beschadiging van een transportkabel door graafwerkzaam-

7 Ook de kosten van al dan niet gesubrogeerde ziektekostenverzekeraars en verhaalsgerechtigde sociale verzekeraars en andere risicodragers (zoals loondoorbetalende werkgevers) vat ik onder de noemer derdenschade.

8 Zie par. 3.2

9 Of andere scheepseigenaren, vgl. HR 7 mei 2004, NJ 2006, 28I, m.nt. Jac. Hijma, Duwbak Linda. 
heden). Als deze derden de schadeveroorzaker hiervoor aansprakelijk stellen, gelden er voor sommigen van deze gevallen bijzondere beperkingen op de grond dat er sprake is van derdenschade, maar in andere gevallen niet. ${ }^{\text {IO }}$

- De laatste categorie derdenschade betreft derdenschade door zuivere vermogensschade van de primair benadeelde. Denk aan het koersverlies van aandelen of het onvoldaan blijven van de vorderingen van schuldeisers als gevolg van de benadeling van een bedrijf. Naar geldend recht hebben aandeelhouders jegens degene die aansprakelijk is voor de benadeling van de vennootschap in beginsel geen recht op schadevergoeding. De verhaalsmogelijkheden van schuldeisers zijn iets beter. ${ }^{\text {II }}$

Deze voorbeelden laten zien dat de opvolgende 'schakels in de schadeketen' verschillende posities innemen ten aanzien van het schadefeit. Bij elk van deze voorbeelden had de derde bepaalde verhaalsmogelijkheden jegens de schadeveroorzaker, maar in sommige gevallen gelden daarbij bijzondere beperkingen en in andere gevallen juist niet. Voor die verschillen worden doorgaans geen systematische redenen aangegeven. De gevallen worden behandeld als kwesties van 'kabelschade' of 'afgeleide schade van aandeelhouders'.

\section{I.3 Eerste aanzet naar een ander perspectief, of beter: naar twee perspectieven}

Hier is een beter perspectief mogelijk. Het thema derdenschade balanceert op het koord van twee aannames: de aanname dat derdenschade door de schadeveroorzaker moet worden vergoed én de aanname dat de verhaalsmogelijkheden bij derdenschade juist moeten worden beperkt. Dit preadvies gaat over het vertrekpunt van die aannames: wat verklaart dat schade die indirect is ontstaan toch wordt vergoed?

Hiermee bedoel ik niet te stellen dat derdenschade in beginsel niet door de schadeveroorzaker zou behoren te worden vergoed. Mijn analyse laat nu juist zien dat de uitsluiting van 'derdenschade'of 'afgeleide schade' en zelfs al het spreken in termen van 'de primair benadeelde respectievelijk de derde' in de praktijk zeer lastig hanteerbaar is. Zij lijkt, zoals we hierna nog zullen zien, ook vaak onredelijk omdat het onderscheid met de schade van eerdere en latere schakels doorgaans niet scherp is. Bovendien is derdenschade nu eenmaal moeilijk uit de samenleving weg te denken, waardoor een a priori-uitsluiting van (vormen van) derdenschade al gauw onder druk komt te staan. Burgers en organisaties raken door bepaalde maatschappelijke ontwikkelingen en tendensen, ondanks de individualisering, met elkaar verbonden. Sociaalwetenschappelijk onderzoek wijst daarop met betrekking tot de digitalisering van communicatiemiddelen, ${ }^{12}$ maar er wordt ook een verbondenheid

Io Zie par. $3 \cdot 3$.

II Zie par. $3 \cdot 4$ resp. par. $3 \cdot 5$.

I2 Empirisch onderzoek wijst op méér, doelgerichter, doch oppervlakkiger contacten en wel ook de versterking van bestaande sociale netwerken, aldus Y. Benkler, The Wealth of Networks. How Social Production Transforms Markets and Freedom, New Haven en Londen: Yale University Press, 2006, p. 356 e.v. Vgl. W. Van de Donk, 'Knooppunten van vertrouwen. Over netwerken, gemeenschaps- 
bevordert in vermogensrechtelijke zin. Denk aan verschillende vormen van solidariteit die bijvoorbeeld verband houden met inperkingen van de sociale zekerheid, de toenemende vergrijzing en de deprivatie van bepaalde stadsbuurten.13

Zulke ontwikkelingen hebben hun weerslag op de juridische benadering van derdenschade: naarmate bijvoorbeeld de afhankelijkheid van naasten om zorgtaken op zich te nemen voor mensen die deze zorg behoeven groter wordt, ligt het meer voor de hand om ook de verhaalsmogelijkheden te verbeteren. ${ }^{\mathrm{I}}$ Maar vooral in de financiële sfeer (aandeelhouders, schuldeisers) wordt er ook juist gewezen op de eigen verantwoordelijkheid van derden om, wanneer ze zich aan anderen verbinden, vooraf goed na te denken over de vermogensrisico's die daarbij horen en om, als ze ervoor kiezen die risico's toch aan te gaan, zich daar dan zelf tegen te beschermen.

Het spanningsveld kenmerkt zich dus in feite door twee polen of perspectieven. De ene pool wordt ingegeven vanuit een visie op de derde als de 'hulpverstrekker' van de primair benadeelde (het hulpperspectief). De andere pool is juist ingegeven vanuit de visie op de derden als degene die 'beter' hadden moeten weten (het risicoperspectief): dit betreft derden die reeds, voorafgaand aan het schadevoorval, (toen) calculeerbare risico's zijn aangegaan, die zich wellicht ook goed door het contractenrecht laten alloceren en spreiden.

\section{I.4 Gekozen opzet, onderzoeksmethode en analytisch kader}

\subsubsection{Opzet van de analyse}

In het licht van die twee perspectieven zal ik een aantal gevallen samenbrengen, analyseren en vergelijken om te zien waar ze zich binnen dit spanningsveld precies begeven. Hangt de vraag of het ene dan wel het andere perspectief wordt gekozen samen met de aard en inhoud van de rechtsbetrekking waarin de derde staat tot de primair benadeelde? De bedoeling is om vanuit de genoemde perspectieven gemeenschappelijkheden en verschillen tussen deelterreinen van derdenschade te kunnen

werking en een menseneconomie', rede beschikbaar via http://www.vu.nl en M. Castells, The Rise of the Network Society, The Information Age: Economy, Society and Culture: Volume I, John Wiley and Sons Ltd, 2009, p. 467 e.v., die uitvoerig laat zien hoe de traditionele werk- en gezinsstructuren geraakt worden door de 'shortening en supersession of time' (p. 473).

I3 Vgl. A.E. Komter, Het cement van de samenleving, Amsterdam: Amsterdam University Press, 2000, p. III, die weerspreekt dat solidariteit door bijvoorbeeld schaalvergroting (p. 7I) of institutionele veranderingen algemeen zou zijn afgenomen; voorts W. Arts, H.B. Entzinger \& R. Muffels (red.), Verzorgingsstaat vaar wel. Kernuragen van de hedendaagse verzorgingsstaat, Assen: Koninklijke Van Gorcum BV, 2003, p. 3. R. Castel, 'The Road to Disaffiliation: Insecure Work and Vulnerable Relationships', International Journal of Urban and Regional Research, 2000, vol. 24.3, p. 519-535 signaleert echter wel een toenemende kwetsbaarheid in de samenleving door 'an impoverishment of support from relationships' (p. 529).

I4 E.F.D. Engelhard, 'Naar een nieuw criterium voor de vergoeding van derden: het voorontwerp Inkomensschade en het wetsvoorstel Re-integratiekosten', VR 2008, p. I e.v. (2008c). 
blootleggen. ${ }^{15}$ Dat biedt de mogelijkheid om algemene inzichten over het thema te ontwikkelen teneinde aan de ontwikkelingen inzake derdenschade betekenis te kunnen geven. Er is volgens mij behoefte aan zo'n fundamentele benadering, aangezien er nog zeer casuïstisch wordt omgegaan met de vraag of er reden is voor een uitbreiding van aansprakelijkheid naar derdenschade. Mij lijkt datwe, pas als het antwoord op deze vraag er is, toekomen aan de vraag waar dan de grenzen liggen en wat de 'juiste' of wenselijke technieken daarvoor zijn. De vergelijking van gevallen laat belangrijke gelijkenissen zien tussen de te bespreken deelterreinen. Daar zal ik algemene conclusies aan verbinden.

De gevallen zullen op twee specifieke punten worden geanalyseerd en vergeleken. Het eerste punt betreft het onderscheid tussen de vraag of derdenschade door de (initiële) schadeveroorzaker wordt en behoort te worden vergoed en de vraag wie het vorderingsrecht (en de actie) toekomt en behoort toe te komen: de primair benadeelde of de derde zelf. Ik mis de scherpte van dit onderscheid bij de vraag naar de verhaalsmogelijkheden van derden jegens de schadeveroorzaker op de deelterreinen. Beide vragen zal ik daarom afzonderlijk aan de orde stellen, zij het dat dit hoofdzakelijk geïntegreerd vorm zal krijgen (door de kwalificatie van bepaalde argumenten of discussies als betrekking hebbend op de ene dan wel de andere vraag).

Het tweede punt betreft de (rechts)betrekking ${ }^{16}$ van derden tot de persoon, bepaalde zaken of het vermogen van de primair benadeelde. Deze verhouding ligt per definitie ten grondslag aan derdenschade. Het ligt dus voor de hand dat zij van invloed is op de verhaalsmogelijkheden van derden jegens de schadeveroorzaker. Ik zal globaal nagaan of en hoe zij een rol speelt bij de argumenten voor of tegen die verhaalsmogelijkheden en bij de uitbreiding of beperkingen daarvan, om te zien of we daar algemene inzichten aan kunnen verbinden.

\subsubsection{Methode en analytisch kader}

De methode van het onderzoek bestaat uit een vergelijking van verschillende typen gevallen op deelterreinen van het (buitencontractuele) aansprakelijkheidsrecht. ${ }^{17}$ Voor de analyse van de gevallen afzonderlijk is gebruik gemaakt van klassieke onderzoeksmethoden, waarbij ik vooral rechtspraak heb geraadpleegd, nu daar de concrete afbakeningsproblemen in aan de orde komen. Voor de vergelijking van gevallen zullen drie vragen inhoudelijk centraal worden gesteld:

I5 De te bespreken deelterreinen zijn afgestemd met de Belgische preadviseurs I. Boone en B. Wylleman.

I6 We zullen hoofdzakelijk gevallen tegenkomen waarin er sprake is van een rechtsbetrekking tussen de primair benadeelde en de derde, daarom zal ik in par. I.4.2 alleen die term gebruiken.

I7 Dit preadvies is beperkt tot buitencontractuele aansprakelijkheid met een schuldgrondslag. 
I. Is de (initiële) schadeveroorzaker, die aansprakelijk is jegens de primair benadeelde, (ook) aansprakelijk voor derdenschade ${ }^{18}$

2. Zo ja, komt het vorderingsrecht dan toe aan de primair benadeelde en/of aan de derde zelf?

3. In hoeverre zijn de aard en inhoud van de rechtsbetrekking waarin de derde staat tot de primair benadeelde van invloed op het antwoord op deze vragen?

Deze vragen bevorderen de systematische vergelijking van de gevallen en maken het mogelijk om nieuwe inzichten te verkrijgen voor het antwoord op de kernvraag.

\section{I.5 Plan van aanpak}

Aangevangen wordt met een bespreking van algemene technieken om de aansprakelijkheid voor derdenschade te begrenzen (paragraaf 2). Dit is de basis voor de analyse van vergoedingsregels op specifieke deelterreinen, die de kern vormt van dit preadvies (paragraaf 3). Na een korte introductie (paragraaf 3.I) worden achtereenvolgens vergoedingsregels geanalyseerd voor derdenschade die verband houdt met: de persoon van de primair benadeelde (paragraaf 3.2), diens zaken (paragraaf 3.3 ) en diens vermogen (paragraaf 3.4 en 3.5 ). Besloten wordt met een overkoepelende conclusie (paragraaf 4 ).

\section{De technische kant van het verhaal}

\section{I Een stapeling van zes technieken}

Maar zoals gezegd vraagt eerst de technische kant van het verhaal aandacht. Het gaat mij er hierbij om de theoretische basis te leggen voor de analyse op deelterreinen. Opmerking verdient echter dat deze paragraaf niet louter beschrijvend is. Ik beschrijf het systeem zoals ik het zelf zie en beperk me tot de relevantie hiervan voor derdenschade. Deze bespreking blijft beperkt tot gevallen waarin de vordering van de derde berust op wettelijke aansprakelijkheid op een schuldgrondslag (art. 6:I62 BW). Andere gronden voor aansprakelijkheid en de contractuele positie van derden blijven buiten beschouwing.

Voor derdenschade die verband houdt met de persoon van de primair benadeelde geldt een gesloten regime; dit zal ik eerst bespreken (paragraaf 2.2). Buiten het terrein van personenschade worden (uitsluitend) algemene technieken gebruikt voor de uitbreiding en afbakening van derdenschade. Deze technieken vallen in essentie samen met de algemene voorwaarden voor aansprakelijkheid: schending van een zorg-

I8 Ik zal er hier steeds vanuit gaan dat de schadeveroorzaker de initiële en daarmee óók de derdenschade heeft veroorzaakt en dat alleen hij voor het schadevoorval aansprakelijk is. De situatie van medeschuldenaren, waarin óók de primair benadeelde jegens de derde aansprakelijk is, blijft hier buiten beschouwing, doch zie par. 3.3.9. 
plicht (paragraaf 2.3), relativiteit (paragraaf 2.4), schade (paragraaf 2.5) en causaliteit (paragraaf 2.6). Besloten wordt met een evaluatie (paragraaf 2.7).

Bijzondere wijzen van begrenzing, zoals de limitering van het recht op schadevergoeding bij vervoersaansprakelijkheid, ${ }^{19}$ blijven buiten beschouwing. Een specifieke beperking voor derden die ik in paragraaf 2 niet zal bespreken, maar die we in paragraaf 3 zullen tegenkomen, is dat de curator bij faillissement praktische 'voorrang' heeft op bepaalde derden. Die regel heeft echter niet de bedoeling om derdenschade te begrenzen en kan dus voorlopig buiten beschouwing blijven.

\subsection{Wettelijke limitering én exclusiviteit bij personenschade}

\subsubsection{Uitbreiding van de verhaalsmogelijkheden}

Meer dan op andere deelterreinen van derdenschade is er bij personenschade sprake van een (wettelijke) uitbreiding van de verhaalsmogelijkheden voor derden: degene die aansprakelijk is voor letsel of overlijden moet niet alleen degene met het letsel schadeloos stellen, maar óók derden die bijzondere wettelijke verhaalsrechten kunnen inroepen, zij het binnen de grenzen van het desbetreffende verhaalsrecht. ${ }^{20} \mathrm{Het}$ bijzondere is dat deze verhaalsrechten recht geven op verhaal ongeacht of er jegens die derden zelf een zorgplicht is geschonden en/of ze zelf door de geschonden norm worden beschermd. De wetgever laat hun in feite 'meeliften' op de aansprakelijkheid jegens de primair benadeelde. Ze hebben dus een gunstiger verhaalspositie dan ze onder het algemeen aansprakelijkheidsrecht zouden hebben.

Onduidelijk is op welke gronden of rationes deze bevoorrechte positie precies berust. ${ }^{21}$ Voor zover de wetsgeschiedenis op dit punt al echt duidelijkheid biedt, ${ }^{22}$ wordt er gesteld dat de schade daar moet worden gelegd waar zij wordt veroorzaakt. Degene die voor het veroorzaken van de initiële schade jegens de primair benadeelde aansprakelijk is, behoort niet te profiteren van het feit dat derden (schadeverzekeraars, sociale risicodragers, naasten) deze schade voor hun rekening nemen. De gedachte is dat deze derden met het overnemen van de schade aan een verplichting voldoen die anders op de aansprakelijke zou rusten. ${ }^{23}$

\subsubsection{Grenzen van de uitbreiding: limitatieve uitbreiding}

Uiteraard kent die bevoorrechte positie grenzen. Strikt genomen gaat het om drie begrenzingen. De wettelijke verhaalsrechten gelden om te beginnen uitsluitend voor wettelijk genoemde derden. Maar in feite voorziet de wet in verhaalsrechten voor alle derden die schade voor hun rekening nemen. ${ }^{24}$ Professionele risicodragers

Vgl. bijvoorbeeld HR I9 september I997, NJ I998, 886, Deutsche Binnenreederei v. Romkes c.s., m.nt. M.H. Cleiringbould.

20 Zie bijvoorbeeld artikel 6:107, I07a en ro8 BW.

2 Z Zie hierover uitvoerig E.F.D. Engelhard, Regres, Deventer: Kluwer, 2003, p. I99 e.v.

22 Het gaat dan in feite om de wettelijke regresrechten voor sociale risicodragers.

23 Engelhard 2003, p. 222.

24 Engelhard 2003, p. 2 en p. 73 e.v. 
(werkgevers, schadeverzekeraars en sociale verzekeraars) hebben een verhaalsrecht jegens de schadeveroorzaker en ook komt een verhaalsrecht toe aan andere derden naar wie letselschade zich 'anders dan krachtens verzekering' heeft verplaatst. ${ }^{25} \mathrm{Het}$ gaat dan bijvoorbeeld om de (kosten van) huishoudelijke taken die naasten voor hun rekening nemen.

De belangrijkste begrenzing betreft de schade(posten) die derden kunnen verhalen. Die zijn beperkt tot schade die zonder tussenkomst van de derde door de primair benadeelde zelf zou zijn geleden. ${ }^{26}$

Ten derde zijn de wettelijke verhaalsrechten beperkt tot het 'civiele plafond': het bedrag waarop de primair benadeelde jegens de schadeveroorzaker recht zou hebben gehad als hij die kosten zelf had moeten dragen. Dit komt erop neer dat de schadeveroorzaker aan de derde dezelfde verweermiddelen kan tegenwerpen als die hij jegens de primair benadeelde zou hebben gehad. Het verhaalsrecht van derden kan bijvoorbeeld dezelfde beperkingen ondergaan van de eigen schuld van de primair benadeelde. ${ }^{27}$ Ook gebreken met betrekking tot de onrechtmatigheid, relativiteit of causaliteit binnen de rechtsverhouding tussen de schadeveroorzaker en de primair benadeelde kunnen aan derden worden tegengeworpen.

Naast deze algemene begrenzingen gelden voor verhaalzoekende verzekeraars overigens nog enkele specifieke beperkingen, die overwegend op politieke gronden berusten. Het voert in het kader van dit preadvies te ver om die hier te bespreken. ${ }^{28}$ Ik houd het erop dat de drie algemene technieken zelf niet zozeer aansprakelijkheid voor derdenschade beperken (terugdringen), maar veeleer grenzen stellen aan de genoemde uitbreiding.

\subsubsection{Een superbeperkende uitleg}

De manier waarop de Hoge Raad het gesloten systeem van verhaalsrechten uitlegt, is echter beperkter dan 'limitatief': volgens vaste jurisprudentie komt derden bij letsel of overlijden zelfs géén 'normaal', rechtstreeks beroep toe op het aansprakelijkheidsrecht. ${ }^{29}$ Buiten het bijzondere, bevoorrechte regime komt hun geen beroep toe op het aansprakelijkheidsrecht. Anders gezegd: derden kunnen zich er niet op beroepen dat de schadeveroorzaker (ook) rechtstreeks jegens hun zélf onrechtmatig heeft gehandeld. Ze kunnen dus niet langs de normale weg tegen directe

25 Zie artikel 6:107 BW.

26 Dit wordt in de meest algemene zin van het woord bepaald door artikel 6:107 BW, maar de verhaalsrechten voor professionele risicodragers hebben eveneens betrekking op - zij het zeer specifieke vormen van - verplaatste schade.

27 Zie artikel 6:I07 lid 2 en artikel 6:Io8 lid 3 BW en uitvoeriger, ook ten aanzien van de regresrechten van particuliere verzekeraars en sociale risicodragers, Engelhard 2003, p. I42 e.v. en 233 e.v.

28 Het gaat om het 'collegaverweer', de Tijdelijke regeling verhaalsrechten (artikel 6:I97 BW) en de regel dat verhaalzoekende verzekeraars niet kunnen profiteren van de zgn. 50\% en roo\% regels voor ongemotoriseerde verkeersslachtoffers. HR 5 december I997, NJ I998, 400-402, m.nt. Jac. Hijma, Terminus v. ZAO c.s., en daarover Engelhard 2003, p. 262 e.v.

29 HR I2 december I986, NJ I987, 958, m.nt. CJHB, Rockwool v. Poly en HR 8 september 2000, NJ 2000, 734, Baby Joost en in die zin reeds o.m. Engelhard 2003, p. 378 e.v. 
rechtsinbreuken opkomen. De onderneming bijvoorbeeld die door schending van de Hinderwetvergunning van een naburig gelegen bedrijf met zieke werknemers kampt en daardoor een omzetverlies heeft, kan daarvoor geen schadevergoeding vorderen.

Met het oog hierop kan serieus worden betwijfeld of deze uitleg van de Hoge Raad wel verenigbaar is met onze verplichtingen onder Europese mensenrechtenverdragen..$^{\circ}$ Volgens mij dwingen de inhoud, ratio en systematiek van het wettelijk systeem van verhaalsrechten bovendien niet tot een zo absolute uitsluiting: bij een 'normaal', rechtstreeks beroep op het aansprakelijkheidsrecht kunnen derden namelijk niet 'meeliften' met de aansprakelijkheid jegens de primair benadeelde. ${ }^{3 \mathrm{I}}$ Hun verhaalsmogelijkheden zouden dan worden beperkt door onder meer het relativiteiten causaliteitsvereiste. Overigens berust de uitsluiting zelf niet op een toepassing van het relativiteitsvereiste: ook de derden die door de geschonden norm worden beschermd, hebben namelijk geen rechtstreekse aanspraak op (volledige) schadevergoeding. ${ }^{32}$

\subsection{Schending van een zorgplicht}

Buiten het personenschaderecht kunnen derden wel rechtstreeks het aansprakelijkheidsrecht inroepen. Het gaat dan om derdenschade die verband houdt met zaakschade of zuivere vermogensschade van de primair benadeelde. ${ }^{33}$ De indirecte totstandkoming van de schade leidt dan tot beperkingen in het kader van de algemene voorwaarden voor aansprakelijkheid. Deze voorwaarden fungeren daarmee als technieken voor de begrenzing van de (omvang van de) aansprakelijkheid.

De voornaamste algemene techniek voor derdenschade betreft de voorwaarde(n) dat sprake is van de (schending van een) zorgplicht. Voor foutaansprakelijkheid is in het algemeen nodig dat de schadeveroorzaker met het oog op belangen van de benadeelde anders had moeten handelen dan hij heeft gedaan. Daarvoor is ten minste vereist dat hij op die belangen bedacht had moeten zijn. ${ }^{34}$ Daarnaast wordt er bij

30 O.m. artikel 6 EVRM en artikel I EP bij het EVRM. Discussie is er buiten personenschade vooral over de uitsluiting van aandeelhouders, EHRM 24 oktober I995, NJ I996, 375, m.nt. Ma v. EEA, Agrotexim Hella c.s. v. Griekenland, r.o. 73, Kroeze 2007, p. 7I, J.C. Van Apeldoorn, 'Artikel I Eerste Protocol EVRM en de positie van de aandeelhouder (Poot v. ABP Revisited)', TvI 2009, afl. 4, p. 2I (die ook Luxemburgse rechtspraak bespreekt). Voorts E.F.D. Engelhard: '(Staats)aansprakelijkheid bij de schending van EVRM-rechten in het "grijze" gebied', Preadvies voor de Staatsrechtkring, in: De aangesproken staat: verantwoordelijkheid, aansprakelijkheid en immuniteit van de overheid, L. Besselink \& R. Nehmelman (red.), Nijmegen: Wolf, 2010.

3I Zie uitvoeriger o.m. Engelhard 2003, p. I55 en 379.

32 HR I2 december I986, NJ 1987, 958, m.nt. CJHB, Rockwool v. Poly.

33 Voor derdenschade door letsel of overlijden volstaat het om te stellen dat de schadeveroorzaker jegens de primair benadeelde zelf (degene met het letsel) een zorgplicht heeft geschonden; zie par. 2.2 en par. 2.7 .

34 O.a. Asser v. Hartkamp \& Sieburgh 6-II*, De verbintenis in het algemeen, tweede gedeelte, Ize druk, 2009, HR 27 januari I984, NJ I984, 536, m.nt. G, Verstekeling en HR 30 september I994, NJ I996, I96-I98, m.nt. CJHB, Bodemverontreiniging, doch zie ook HR I4 oktober 2005, NJ 2007, 270, Unocal en DSM v. Conoco c.s. Vgl. ook het ontbreken van schuld (de Staat 'kon niet weten'): Hof Den Haag 24 augustus 20I0, LJN BN43I6, Enschede. 
de vraag of er een zorgplicht is geschonden gelet op relevante factoren, zoals de wijze waarop de schade tot stand is gekomen en de aard en voorzienbaarheid van de schade. Het gegeven dat onzorgvuldig is gehandeld jegens een vennootschap, betekent bijvoorbeeld nog niet dat dit ook jegens aandeelhouders het geval is, en het oordeel dat er een geschonden zorgplicht is jegens de eigenaar en directe gebruiker van een stroomkabel, beschermt veelal niet ook de contractuele belangen van diens afnemers. ${ }^{35}$

De scheidslijn met de andere voorwaarden voor aansprakelijkheid, en met name het toerekenbaarheidsvereiste (art. 6:I62 lid 3 BW) is niet scherp; het is in verband hiermee dat ik de toerekenbaarheid niet afzonderlijk noem als techniek ter begrenzing van aansprakelijkheid. Dit vereiste heeft over het algemeen voor derdenschade een te geringe zelfstandige betekenis naast de vraag of de schadeveroorzaker 'maatschappelijk onbetamelijk' heeft gehandeld. ${ }^{36}$ Ook de zelfstandige betekenis van de andere on rechtmatigheidscriteria (strijd met een wettelijke plicht en het inbreukcriterium) is specifiek voor de begrenzing van derdenschade betrekkelijk. Toch biedt ook het inbreukcriterium (van art. 6:I62 BW) wel een afbakening voor derden. Denk aan de vraag of het recht van family life van artikel 8 EVRM meebrengt dat een medische kunstgreep jegens een kind ook onrechtmatig is jegens zijn ouders. ${ }^{37}$ Maar veelal zijn met de toetsing aan deze criteria concurrerende, 'hogere' belangen gemoeid, die meebrengen dat ze zelden zelf specifiek op derdenschade toegesneden beperkingen zullen opwerpen. De beperkingen komen hier (en bij het wettelijke plichtcriterium van artikel 6:I62 BW) veelal van aanvullende technieken, waarover hierna meer volgt.

\subsection{Strekking van de geschonden norm (relativiteit)}

Bij strijd met een wettelijke plicht kan het aspect van derdenschade in het kader van het relativiteitsvereiste tot verschillende beperkingen leiden: van aansprakelijkheid is namelijk geen sprake indien de geschonden norm niet strekt tot bescherming van de hoedanigheid van de benadeelde, het type schade waarvoor vergoeding wordt gevorderd en de wijze waarop de schade is ontstaan..$^{8}$ Dit kan een uitvoerige zoektocht vergen naar de door de wetgever beoogde strekking.

Er is (met name) de laatste jaren echter op gewezen dat de strekking van de wetsbepaling over het algemeen lastig is te achterhalen en er wordt getwijfeld aan de

35 Zie resp. par. $3 \cdot 4 \cdot 3$ en par. 3.3.8.

36 Het ontbreken van toerekening wordt uitzonderlijk genoemd, zie Spier/Hartlief/Van Maanen/ Vriesendorp 2009, nr. 74 (Van Maanen), doch zie ook Asser/Hartkamp \& Sieburgh 6-II*, De verbintenis in het algemeen, tweede gedeelte, Ize druk, 2009 en D.A.M.H.W. Strik, 'Ernstige verwijtbaarheid: tussen onrechtmatigheid en toerekenbaarheid', Ondernemingsrecht 2009, p. 660-67I, die juist meer aandacht vraagt voor het toerekenbaarheidsvereiste in het kader van artikel 2:9 BW en bijvoorbeeld Hof Arnhem I7 augustus 20I0, LJN BN3795, Alliander v. Vink Aannemingsmaatschappij, r.o. 4.7 .

37 Vgl. HR 8 september 2000, NJ 2000, 734, Baby Joost.

38 Zo wordt artikel 6:I63 BW geïnterpreteerd; zie bijvoorbeeld HR 7 mei 2004, NJ 2006, 28I, m.nt. Jac. Hijma, Duwbak Linda. 
meerwaarde van deze focus op de wetshistorie, aangezien het daarbij nu juist veelal om onvoorzienbare implicaties van de schending gaat. Daar komt bij dat de beschermende strekking van gedragsnormen sowieso al vaak onduidelijk is, op verouderde inzichten berust en/of niet zichtbaar bijdraagt aan het eindoordeel. ${ }^{39}$

\subsection{Schadetechnieken}

Kan het beschermingsbereik van wettelijke gedragsnormen niet 'gewoon' los van de inhoud van de geschonden norm door de rechter worden beperkt? Het schadevereiste biedt daar in theorie aanknopingspunten voor, maar behelst naar geldend recht veelal niet meer dan de voorwaarde dat er feitelijk gezien sprake is van schade. Er moet een verslechtering zijn van de (vermogens)toestand. ${ }^{4}$ Het schadebegrip heeft ook wel een zekere normatieve component. Zo zien we dat uitsluitend rechtmatige belangen worden beschermd en dat 'abstracte' schade soms wordt vergoed. ${ }^{4 \mathrm{I}}$ Maar we zien dit vooral aan het feit dat 'affectieschade' (het verdriet van naasten) niet wordt vergoed; zie paragraaf 3.2.3. Afgezien hiervan worden er in het kader van het schadevereiste echter geen algemene eisen gesteld.

In sommige andere rechtssystemen wordt wel met vergaande technieken gewerkt waarbij bepaalde 'schade' van het recht op schadevergoeding wordt uitgesloten. ${ }^{42}$ Die laten echter zien dat een zo mechanisch aan banden leggen van de verhaalsmogelijkheden onpraktisch is en mogelijk tot complicaties leidt in het licht van verdragsrechtelijke verplichtingen. ${ }^{43}$ Gedupeerden kunnen niet op deze indirecte wijze worden uitgesloten van de rechtsgang naar de burgerlijke rechter en de schadepraktijk is ook eigenlijk te weerbarstig voor zulke categorische uitsluitingen van schade. We zullen hierna zien dat niet alleen de uitsluiting van affectieschade (en andere schade door letsel of overlijden), maar bijvoorbeeld ook de vergaande beperkingen van de schade van aandeelhouders de laatste jaren steeds meer onder druk staan. Zo is met name ook uit de uitsluiting van affectieschade het fenomeen van 'shockschadevorderingen' voor derden geboren. ${ }^{44}$

Zie o.a. S.D. Lindenbergh, 'De betrekkelijkheid van de geschonden norm. Een verweer dat dwingt tot principiële keuzes', TVP 2008, p. 907-9II (2008b), nr. 5 (met verwijzingen). Een van de stellingen bij de dissertatie van Visscher (L.T. Visscher, Een rechtseconomische analyse van het Nederlandse onrechtmatigedaadsrecht, Den Haag: BJu, 2006) luidt ook dat het relativiteitsvereiste moet worden afgeschaft.

S.D. Lindenbergh, Schadevergoeding: algemeen, deel 1, Monografieën BW, B34, Deventer: Kluwer, 2008 (2008a), p. 47 e.v.

4I Zie bij de schadebegroting bijvoorbeeld HR 24 november 2000, NJ 200I, I95, m.nt. ARB, 'Zwart' loon en hierna, par. 3.2.2.

42 Een landenoverzicht wordt geboden door de Studygroep on a European Civil Code, Non-Contractual Liability Arising out of Damage Caused to Another, Chr. Von Bar, Munich: Sellier, 2009, p. 303 e.v.

43 Zie reeds par. 2.2.

44 Zie o.a. HR 8 april 1983 , NJ I984, 7I7, m.nt. CJHB, Van der Heijden v. Holland en zie hierna, par. 3.2.6. 


\subsection{Dubbele causaliteitstoets (en andere schademechanismen)}

Een vierde techniek om de aansprakelijkheid voor derdenschade te beperken biedt het vereiste van causaliteit. In feite worden hier twee technieken gebruikt: eerst wordt nagegaan of er tussen de onrechtmatige daad en de schade een conditio sine qua non-verband is en daarna wordt nog op normatieve gronden bepaald in hoeverre de schade aan de schadeveroorzaker moet worden toegerekend (art. 6:98 BW).

Het conditio sine qua non-criterium lijkt voor derdenschade vooral van betekenis bij de vorderingen van aandeelhouders en schuldeisers in verband met benadeling van de vennootschap. Op zichzelf staat het gegeven dat er feitelijk twee schadeoorzaken zijn (het gedrag van de schadeveroorzaker en de schade van de primair benadeelde) evenwel niet aan de vaststelling van dit verband in de weg. ${ }^{45}$ Specifiek bij derdenschade ligt het gewicht dan ook vooral bij de normatieve causaliteit. ${ }^{46}$ Is causale toerekening 'redelijk', bijvoorbeeld gelet op de voorzienbaarheid, verzekerbaarheid en aard van de derdenschade (het afgeleide karakter)? Primair wordt dit toerekeningsverband aanwezig geacht; het is aan de schadeveroorzaker om, als hij het betwist, met tegenargumenten te komen. ${ }^{47}$

\subsection{Evaluatie}

Hiervoor heb ik de belangrijkste technieken genoemd voor vorderingen tot vergoeding van derdenschade op een schuldgrondslag. De indirecte totstandkoming van derdenschade leidt met name tot specifieke, daarop toegesneden beperkingen bij de vraag naar de schending van een zorgplicht en bij de beoordeling van de relativiteit en de (normatieve) causaliteit. In veel mindere mate wordt het schadevereiste ingezet.

Dit is anders bij derdenschade door letsel of overlijden. Dan bepalen deze technieken ook wel of er een grond is voor (fout)aansprakelijkheid, maar die vraag heeft dan (in beginsel $4^{48}$ betrekking op de verhouding zoals die ten tijde van het schadevoorval bestond tussen de schadeveroorzaker en de primair benadeelde. Voor de vaststelling van de aansprakelijkheid speelt de problematiek van derdenschade hier dus, strikt genomen, geen enkele rol. Het is natuurlijk moeilijk om vast te stellen of bij de beoordeling van de aansprakelijkheid 'onuitgesproken' niet toch van invloed

45 Het is bijvoorbeeld ook niet vereist dat het gedrag van de aangesprokene de causa proxima is.

46 Artikel 6:98 BW; met betrekking tot de leer zelf H.K. Köster, Causaliteit en voorzienbaarheid. De betekenis van de begrippen causaliteit en voorzienbaarheid voor de omvang van de buitencontractuele schadevergoeding, rede Amsterdam, Zwolle I963 en A.R. Bloembergen, Schadevergoeding bij onrechtmatige daad, Deventer: Kluwer, I965 en C.J.H. Brunner, 'Causaliteit en toerekening van schade', VR I98I, p. 2Io e.v. en bij presdisposities, o.a. HR 8 februari I985, NJ I986, I36, m.nt. CJHB, Joe CBIC, m.nt. CJHB, HR 8 februari I985, NJ I986, I37, m.nt. CJHB, Renteneurose en HR 4 november I988, NJ I989, 75I, m.nt. CJHB, ABP v. Stuyvenberg.

47 Zie nr. 3.32 e.v. van A-G Spier's Conclusie voor HR 2 oktober I998, NJ I998, 831, Nacap v. International Shellfish, gevolgd door o.a. Hof Arnhem I6 maart 20Io, LJN BL8028, Liander v. Bouwcombinatie c.s., r.o. 4.I6.

48 Een uitzondering geldt voor derden met shockschade: de aansprakelijkheid ingevolge het Taxibus-arrest berust wel op de verhouding tussen de schadeveroorzaker en de derde zelf. 
is dat de aansprakelijkheid wordt ingeroepen door de verhaalzoekende verzekeraar (of een andere derde) en niet door de primair benadeelde zelf. ${ }^{49}$ De afbakening van derdenschade geschiedt echter door de wetgever. Bijzondere wettelijke verhaalsrechten geven limitatief aan welke derden voor welke schade een verhaalsrecht toekomt..$^{\circ}$ Ook qua omvang zijn deze verhaalsrechten wettelijk beperkt, met name door het civiele plafond. De Hoge Raad legt dit gesloten systeem van verhaalsrechten zo uit, dat derden geen rechtstreeks beroep toekomt op het aansprakelijkheidsrecht.

Voor derdenschade die geen verband houdt met letsel of overlijden (zoals bij leidingschade) ligt de afbakening van de derdenschade in de handen van de rechter, bijvoorbeeld door de toepassing van het relativiteitsvereiste en/of de andere algemene technieken. Het uitgangspunt is dan, in tegenstelling tot de derdenschade door letsel en overlijden, dat de schade voor vergoeding in aanmerking komt, uiteraard binnen de grenzen van het schadevergoedingsrecht (met name afd. 6.I.Io BW). De relativiteit en normatieve causaliteit worden in beginsel behoudens tegenbewijs verondersteld aanwezig te zijn. Hoewel het mij hier niet zozeer om de technieken zelf te doen is, laat ik hierna zijdelings zien dat het zorgplichtvereiste eigenlijk nog de meest vergaande en tegelijk de minst complicerende techniek is voor de afbakening van derdenschade.

\section{Derdenschade op specifieke deelterreinen}

\section{I Overzicht}

Het belang van dit preadvies en van de beoogde rechtsvergelijking ligt zoals gezegd niet bij dit theoretische kader. Waar het om gaat, is de vraag in hoeverre er nu concreet sprake is of zou moeten zijn van een uitbreiding van de verhaalsmogelijkheden van derden en wat de systematische redenen daarvan zijn (of moeten zijn). Met het oog op deze vraag volgt hierna een vergelijkende analyse van gevallen op specifieke deelterreinen; dit deel vormt de kern van dit preadvies. Daarbij zal worden getracht om de vraag of de schade voor vergoeding in aanmerking komt te onderscheiden van de vraag aan wie het vorderingsrecht (en de actie) dan toekomt: aan de primair benadeelde of aan de derde zelf. Beide vragen willen in de discussies op deelterreinen nogal eens door elkaar lopen. Voor beide vragen zal het antwoord worden gezocht bij de rechtsbetrekking van de derden tot de persoon, zaken of het vermogen van de primair benadeelde.

Aangevangen wordt met de derdenschade die verband houdt met de persoon van de primair benadeelde. Hiervoor is binnen de grenzen van bijzondere wettelijke verhaalsrechten verhaal mogelijk op de schadeveroorzaker. ${ }^{\text {II }}$ Deze verhaalsrechten

Voor zover al niet de Tijdelijke regeling verhaalsrechten geldt (artikel 6:I97 BW) of de 'verkeersjurisprudentie' inzake artikel $185 \mathrm{WVW}$, op basis waarvan regresnemers niet meeprofiteren van bescherming die het aansprakelijkheidsrecht de primair benadeelde biedt. HR 5 december I997, NJ I998, 400-402, m.nt. Jac. Hijma, Terminus v. ZAO c.s.,Engelhard 2003, p. 262 e.v.

50 Hartlief 2006, p. 99.

5I Dit kwam hiervoor al aan de orde, zie par. 2.2. 
zien echter slechts op één beperkt deel van de derdenschade die verband houdt met de persoon van de primair benadeelde. Aandacht zal eerst uitgaan naar letsel (paragraaf 3.2.I) en dan naar overlijden (paragraaf 3.2.2). Daarna komen categorieën van derdenschade buiten het terrein van letsel of overlijden aan de orde (paragraaf $3 \cdot 3$, 3.4 en 3.5$)$.

\subsection{Derdenschade in verband met de persoon van de primair benadeelde}

\subsubsection{Het 'hulpperspectief': derden als hulpverstrekker}

Op het terrein van personenschade is 'echte' derdenschade vrijwel volledig verstoken van bescherming. De verhaalsrechten van derden hebben betrekking op schade van de primair benadeelde die zich naar hen verplaatst. De gedachte is dat derden met het overnemen van de schade aan een verplichting voldoen die anders op de aansprakelijke zou rusten..$^{2} \mathrm{Mij}$ lijkt dit zó te verklaren dat de belangen van de primair benadeelde ermee zijn gemoeid dat naasten te hulp schieten. Dit laatste kan worden bevorderd als ze de kosten (en het tijdsverlies) die daarmee gemoeid zijn op de schadeveroorzaker kunnen verhalen. Het ontbreken van verhaalsmogelijkheden zou derden althans ervan kunnen weerhouden om zorg te verlenen en daardoor zou het belang van de primair benadeelde nog verder worden gefrustreerd. In dat geval zou hij immers zelf afhankelijk zijn van de onzekere uitkomst van de civiele procedure, hetgeen bijvoorbeeld zijn herstel zou kunnen belemmeren.

De verhaalsmogelijkheden van derden zijn volledig gericht op hun rol als 'hulpverstrekkers' ten aanzien van de primair benadeelde. Door diens schade voor hun rekening te nemen, voldoen derden aan een verplichting die primair op de aansprakelijke rust. Vandaar ook de al genoemde begrenzing van hun verhaalsrechten tot het 'civiele plafond': het bedrag dat de aansprakelijke zonder hun tussenkomst aan de primair benadeelde verschuldigd zou zijn geweest. Deze benadering van de positie van derden staat de laatste jaren echter onder druk. Er zijn 'barsten in het bolwerk' gesignaleerd..$^{53} \mathrm{Ik}$ zal die hierna bespreken en kort van commentaar voorzien.

Een ander punt dat, als het gaat over de 'emancipatie' van derden, ${ }^{54}$ aandacht vraagt, is wie de vordering toekomt met betrekking tot de schade. Uitgaande van dit 'hulpperspectief' ontberen naasten een volledig zelfstandige verhaalspositie. Sociaalrisicodragers staan sterk in de zin dat ze de enige zijn die hun aanspraak op vergoeding zelfstandig kunnen effectueren. Maar voor naasten en schadeverzekeraars geldt dat de primair benadeelde de schade die ze voor hun rekening nemen ook zelf kan verhalen. Vooral bij naasten kan dit tot complicaties leiden: de primair benadeelde kan stellen dat de zorgkosten deel uitmaken van zijn schade. ${ }^{55}$ Hier is in de Nederlandse literatuur nog weinig aandacht aan besteed, ${ }^{56}$ maar het is wellicht

52 Engelhard 2003, p. 222.

53 Hartlief 2006, p. 102.

54 Deze duiding komt van de mooie bijdrage van Hartlief 2006, p. I02.

55 Zoals het geval was in HR 5 december 2008, NJ 2009, 387, m.nt. JBMV, Rijnstate v. Reuvers.

56 Zie C.C. Van Dam, 'Pecuniary loss of relatives and employers in case of personal injury, A comparison of English and German law', in: 'Third Party Losses in a Comparative Perspective: three 
een punt dat om nadere studie vraagt. De discussies over de verhaalsmogelijkheden voor derden bij letselschade spitsen zich thans echter vooral toe op het niveau van bescherming.

\subsubsection{Uitbreidingen naar naasten bij letsel: (slechts) méér hulpperspectief}

De laatste jaren staan vooral in het teken van naasten die thuis zorgtaken op zich nemen. De Hoge Raad heeft aanvaard dat in dat geval ook puur tijdsverlies als 'verplaatste schade' kan worden aangemerkt, althans waar dit ouders betreft die hun gewond geraakte kind langdurig en intensief thuis hebben verpleegd en verzorgd. De ouders voldoen daarmee volgens de Hoge Raad namelijk 'in natura aan een verplichting die primair rust op de aansprakelijke'.57 Onder omstandigheden mag de rechter hierbij abstraheren van het feit dat er geen concrete schade is (bij kind, noch ouders), mits het gaat om zorgtaken waarvoor het 'normaal en gebruikelijk' is om professionele hulp te krijgen. Wel is de vergoeding beperkt tot het geschatte bedrag van de bespaarde kosten van professionele hulp.

Het criterium van 'professionele hulp die normaal en gebruikelijk is', richt zich in feite op buitengewone zorgtaken en is vooral daarom kritisch ontvangen..$^{8} \mathrm{Het}$ zou de lat te hoog leggen, ook al wordt dit criterium slechts betrokken op particuliere hulp (en dus niet op het kunnen verkrijgen van sociale thuiszorg). Zo was hier niet aan voldaan in het geval waarin de echtgenote van een mesothelioomslachtoffer haar man in de laatste weken voor zijn overlijden had verzorgd, ${ }^{59}$ noch bij de verlofdagen die ouders hadden opgenomen om hun ernstig verwonde kind in de kliniek te bezoeken, en in beginsel sowieso niet bij alledaagse huishoudelijke taken die de naasten op zich nemen, zoals boodschappen doen, koken, de afwas doen, enzovoort. ${ }^{60}$ Maar indien wel aan dit criterium is voldaan, dan betekent dit dat abstracte schade, enkel tijdsverlies, wordt vergoed (zij het slechts beperkt tot de bespaarde kosten van die professionele hulp).

short lectures in honour of W.H.V. Rogers, met E.F.D. Engelhard \& I. Giesen, ULR 2007, p. 70-Ioo, p. 73 e.v. over dit aspect onder Duits en Engels recht.

57 De beperking tot de professionele kosten komt nog van HR 28 mei I999, NJ I999, 564, m.nt. ARB, Gemeente Losser v. De Vries, r.o. 3.3.2; het criterium 'normaal en gebruikelijk' is van later: HR 6 juni 2003, NJ 2003, 504, m.nt. JBMV, Krüter-Van de Pol v. Wilton-Feijenoord.

58 Zie, met verdere referenties, E.F.D. Engelhard, annotatie bij HR 6 juni 2003, NJ 2003, 504, m.nt. JBMV, Krüter-Van de Pol v. Wilton-Feijenoord Holding BV, NTBR 2004, p. 47 e.v., p. 48, S.D. Lindenbergh \& I. Van der Zalm, 'Vergoeding ter zake van verzorging en huishoudelijke hulp bij letsel en overlijden', MvV 2009, p. I46 e.v., p. I48 en R. Rijnhout, 'Vergoeding voor huishoudelijke hulp door naasten: een overkoepelende analyse', AV\&S 2009, p. I79 e.v.

59 HR 6 juni 2003, NJ 2003, 504, m.nt. JBMV, Krüter-Van de Pol v. Wilton-Feijenoord, m.nt. Engelhard 2004, p. 47 e.v.

6o Resp. HR 28 mei I999, NJ I999, 564, m.nt. ARB, Gemeente Losser v. De Vries, de Hof-uitspraak voorafgaand aan HR 5 december 2008, NJ 2009, 387, m.nt. JBMV, Rijnstate v. Reuvers en Rb. Middelburg 24 september 2008, LJN BG5483. AG Spier noemt in zijn Conclusie voor Rijnstate v. Reuvers (nr. 3.10) nog feitenrechtspraak waarin het criterium toepassing vindt. 


\subsubsection{Geen verhaalsrecht voor andere derdenschade?}

Voor 'echte' derdenschade die verband houdt met het letsel van de primair benadeelde, hebben derden geen recht op schadevergoeding. ${ }^{6 \mathrm{r}}$ Te denken valt aan de misgelopen carrièrekansen van de partner van de primair benadeelde die het gevolg is van een stressvolle thuissituatie door het letsel, of bedrijfsschade van de werkgever die tijdelijk geen vervanger vindt. Dat deze zelfstandige schade niet verhaalbaar is, is een nadrukkelijke keuze van de wetgever bij de invoering van het BW: niet-verhaalbare bedrijfsrisico's moest de werkgever in zijn prijzen doorberekenen of verzekeren. $^{62}$

Een zeer minimale uitbreiding van de verhaalsmogelijkheden, beperkt tot de toeschouwers van schadevoorvallen, wordt geboden in het Taxibus-arrest, voor derden die als gevolg van de 'directe' confrontatie met een ernstige schending van een verkeers- of veiligheidsnorm een hevige schok oplopen die tot geestelijk letsel lijdt. Die kunnen een zekere bescherming ontlenen aan de geschonden verkeers- of veiligheidnorm (zonder dat het relativiteitsvereiste of het gesloten wettelijk systeem van verhaalsrechten hier aan in de weg staan). Bij het (naar billijkheid te schatten) bedrag van immateriële schade moet de rechter echter onderscheid maken tussen het verdriet dat voortkomt uit het overlijden van het primaire slachtoffer (dat niet wordt vergoed) en het verdriet door de confrontatie met het ongeval (wel vergoed). ${ }^{6}$ Uit een studie van gepubliceerde feitenrechtspraak uit 2007 blijkt dat deskundigen regelmatig wordt gevraagd om te verklaren dat en ook in hoeverre de shockschade voortvloeit uit het letsel of overlijden. Die verklaring wordt vrijwel nooit gegeven, met als gevolg dat de rechter in een aantal zaken het bedrag van de (immateriële) schadevergoeding slechts voor de helft toewijst. ${ }^{64}$

Er zijn betrekkelijk vage indicaties dat hier in de toekomst mogelijk verandering in komt. In het kader van het wetsvoorstel Affectieschade, dat in het voorjaar van 2010 op principiële gronden door de Eerste Kamer is verworpen, ${ }^{65}$ is er in het parlement gesproken over de wenselijkheid en het belang van een uitbreiding van de vergoedingsmogelijkheden voor de 'harde' vermogensschade van naasten. Informeel, via het internet, kon zelfs al een brief worden gevonden met daarin een reactie op een zogenoemd voorontwerp Inkomensschade van naasten ${ }^{66}$ maar die ontwikkeling heeft tot op heden nog geen concreet vervolg gehad.

6I Doch zie hierna; vgl. HR 8 september 2000, NJ 2000, 734, m.nt. ARB, Baby Joost.

62 Parl. Gesch. (Inv.) Boek 6, p. I28I.

63 HR 20 februari 2002, NJ 2002, 240, m.nt. JBMV, Taxibus.

64 Zie mijn bijdrage 'Visie op (recente rechtspraak over) de Taxibus-criteria conform recente klinische inzichten', VrA 2008, p. 20-46 en ook E.F.D. Engelhard, 'Opzettelijke levensberoving en shockschade', Kort en Bondig, NTBR 2008, p. 307-309 (2008a).

65 En uit zorg voor een 'claimcultuur', zie Kamerstukken I, 2009-Io, 28 781, 23 maart 2010; zie hierover Rijnhout 2010.

66 Zie Engelhard 2008c over dit voorontwerp. 


\subsubsection{Het 'hulpperspectief' bij overlijdensschade}

Het gesloten systeem van verhaalsrechten geldt ook voor de derdenschade door overlijden. Artikel 6:Io8 BW geeft een beperkte kring van nabestaanden in dat geval recht op vergoeding jegens de aansprakelijke voor gederfd levensonderhoud, waaronder ook de weggevallen fysieke bijdrage aan de gezamenlijke huishouding en/ of zorg voor de kinderen valt, ${ }^{67}$ en de kosten van lijkbezorging. Vooral die laatste kostenpost lijkt ook weer te zijn ingegeven door een 'hulpperspectief', al klinkt dat misschien eigenaardig; het zorgdragen voor de kosten van de uitvaart zal veelal in het teken staan van het belang van de primair benadeelde: hoe had die zijn uitvaart gewenst? De vergoeding van gederfd levensonderhoud betreft wel een 'zelfstandige schade'. De vergoeding is dan beperkt tot de mate waarin de financiële middelen van nabestaanden ontoereikend zijn om, met instandhouding van de levensstandaard zoals die zonder het overlijden van de kostwinner zou zijn geweest, zelf in hun levensbehoeften te voorzien. ${ }^{68}$

Toch is dat niet helemaal waar: ook dit heeft een zekere 'hulpcomponent', maar die betreft uiteraard niet de hulp of zorg ten aanzien van de overledene. Tot gederfd levensonderhoud behoort echter ook het weggevallen aandeel van de overledene in huishoudelijke taken en de zorg voor inwonende kinderen. ${ }^{69}$ De aansprakelijke kan hier niet tegenwerpen dat familie, vrienden of andere derden onbetaald in de huishouding voorzien, evenmin als de omstandigheid dat de overgebleven partner een nieuwe partner vindt die een aantal taken, waaronder de zorg voor de kinderen, op zich neemt. ${ }^{70}$ Het wordt niet redelijk geacht als die lasten voor rekening komen van de nieuwe partner. ${ }^{71}$ Wel dient er een concrete behoefte te zijn aan vervanging van het verloren aandeel dat de overledene zonder het ongeval zou hebben gehad. ${ }^{72}$ Ook wordt de overgebleven partner/ouder in beginsel geacht 'bij te springen'. Of en in hoeverre dit het geval is, is afhankelijk van diens aantal werkuren, type werk en de leeftijd van de kinderen.

\subsubsection{Uitbreiding voor nabestaanden bij overlijden: meer hulpperspectief?}

Recenter oordeelde de Hoge Raad echter dat tot het gederfd levensonderhoud van artikel 6:Io8 BW zelfs het inkomensverschil kon worden gerekend van de werkende vrouw die zich na het overlijden van haar man genoodzaakt zag voortaan zelf thuis

67 Niet nodig is dat de overledene het grootste deel van de huishouding voor zijn rekening nam; enig deel is voldoende. Zie HR I6 december 2005, NJ 2008, I86, m.nt. JBMV, Pruiskens v. Organice.

68 O.a. HR 4 februari 2000, NJ 2000, 600, m.nt. MMM, Kwidama v. Raphael-Richardson, zie E.F.D. Engelhard, 'Behoeftigheid bij overlijden', NTBR 2000, p. 254-26o.

69 Dit wordt onderscheiden van het verlies van zelfredzaamheid, dat meer ziet op bijvoorbeeld klusjes en reparaties in en om het huis, hoewel ook die post kan worden vergoed; zie de 'Aanbeveling voor Huishoudelijke Zorg' van de Letselschaderaad.

70 HR I6 december 2005, NJ 2008, I86, m.nt. JBMV, Pruiskens v. Organice.

$7 \mathrm{I}$ Zie HR 5 juni I98I, NJ I982, 22I, m.nt. CJHB, Tijsterman v. Hony en HR 28 februari I986, NJ I987, Ioo, Huiskes en Niks v. Snippe-Meulenbroek en, recenter, HR II juli 2008, NJ 2009, 385, m.nt. JBMV, Bakkum v. Achmea.

72 HR II juli 2008, NJ 2009, 385, m.nt. JBMV, Bakkum v. Achmea. 
te blijven voor haar kind. ${ }^{73}$ Het was onbetwist dat, indien haar echtgenoot nog geleefd zou hebben, hij thuis zou zijn gebleven bij hun dochter om zijn vrouw de mogelijkheid te geven om haar carrière en haar werkuren uit te breiden.

Dat is een uitbreiding: artikel 6:108 BW noemt alleen het verlies van levensonderhoud, niet het inkomensverlies. Dat de weduwe na het overlijden besluit om voor haar kind thuis te blijven, is bovendien een persoonlijke keuze. Maar dit inkomensverlies is dus onder de genoemde omstandigheden in beginsel vergoedbaar. Zoals ik al wel eens eerder heb gesteld, lijkt mij dit een wenselijke uitspraak; deze uitbreiding voorziet ten minste in een oplossing die aansluit bij de maatschappelijke realiteit.74

\subsubsection{Ruimte voor uitdijing naar 'echt' zelfstandige schade?}

Buiten deze gevallen is er in beginsel geen schadevergoeding mogelijk. ${ }^{75}$ Het praktische belang wordt gauw overdreven, maar toch zijn er ook bij overlijden gevallen waarin een direct beroep op het aansprakelijkheidsrecht voor derden van belang kan zijn omdat ze anders met bepaalde schade 'blijven zitten'. Te denken valt natuurlijk aan situaties die bij letsel werden genoemd, maar dan met een dodelijke afloop. Schoolvoorbeelden zijn verder het voetbalteam dat de sterspeler verliest of bedrijven waarvan werknemers als gevolg van de ernstige afloop van een ongeluk in de file staan (en die als gevolg daarvan aantoonbaar bedrijfsschade hebben). Een andere categorie zijn derden met shockschade die anders dan door de 'directe confrontatie' van het Taxibus-arrest is ontstaan (zie paragraaf 3.2.3). Het Hof Arnhem heeft in 2008 geoordeeld dat aan dit criterium was voldaan in de zaak van een moeder wier dochter op gruwelijke wijze is omgebracht, maar die het overlijden of de wijze waarop dit gebeurd is niet had gezien..$^{7}$ Maar in het arrest Vilt oordeelde de Hoge Raad dat voor de confrontatie strikte eisen gelden; daaraan is doorgaans pas voldaan als de eiser het ongeval of de directe gevolgen daarvan gezien heeft. ${ }^{77}$

\subsubsection{Evaluatie}

In het voorgaande werd zichtbaar dat de uitbreiding van de aansprakelijkheid voor derdenschade door letsel of overlijden duidelijk is afgebakend en dat hier stevig de hand aan wordt gehouden. Het uitgangspunt is dat alleen de wet bepaalt wie, voor welke schade en in welke mate een verhaalsrecht toekomt. Hierbij overheerst een 'hulpperspectief': in feite hebben alleen derden die de primair benadeelde te hulp schieten, in de zin dat ze schade van de primair benadeelde voor hun rekening nemen, wettelijke verhaalsrechten tot hun beschikking. Die verhaalsrechten zijn beperkt tot deze verplaatste schade. Daarbij lijkt over het algemeen niet van belang of ze de schade

HR ro april 2009, NJ 2009, 386, m.nt. JBMV, Philip Morris v. Bolink.

Zie Engelhard v. Giesen 20I0, nr. 35 e.v.

75 HR I2 december I986, NJ I987, 958, m.nt. CJHB, Rockwool v. Poly en vgl. HR 8 september 2000, NJ 2000, 734, Baby Joost en daarover Engelhard 2003, p. 378 e.v. Zie voor 'shockschade' par. 3.2.3.

76 E.F.D. Engelhard, 'Visie op (recente rechtspraak over) de Taxibus-criteria conform recente klinische inzichten', VrA 2008, p. 20-46 (2008b).

77 HR 9 oktober 2009, NJ 20I0, 387, m.nt. JBMV, Vilt en daarover Rijnhout 2010. 
van de primair benadeelde verschuldigd of onverschuldigd en in geld of in natura (bijvoorbeeld in de vorm van zorgtaken) op zich nemen. De gedachte is dat ze door hun hulp de verplichting voldoen die anders, zonder hun tussenkomst, op de aansprakelijke zou rusten.

Ik verklaar dit zó dat de belangen van de primair benadeelde ermee zijn gemoeid dat naasten te hulp schieten en dat het schadevergoedingsrecht dit kan bevorderen door te bepalen dat ze de kosten (en het tijdsverlies) die daarmee gemoeid zijn op de aansprakelijke kunnen verhalen. Het ontbreken van deze verhaalsmogelijkheden zou derden ervan kunnen weerhouden om zorg te verlenen en daardoor zou het belang van de primair benadeelde nog verder worden gefrustreerd (doordat hij zelf afhankelijk zou zijn van de onzekere uitkomst van de civiele procedure). ${ }^{78}$

Dat de schade van de primair benadeelde een centrale plaats inneemt, blijkt ook uit het feit dat hij de vordering voor zorgkosten zelf kan instellen. Dit kan voor hem van belang zijn indien hij ondanks het voornemen of de belofte van de naaste om zijn zorg op zich te nemen, daar toch niet helemaal gerust op is. De naaste is dan echter afhankelijk van (adequate) doorbetaling van het ontvangen schadebedrag door de primair benadeelde, zij het dat daar vaak tegenover zal staan dat de primair benadeelde afhankelijk is van zijn zorg (gelet op het persoonlijke karakter daarvan). Wel kunnen naasten de vordering voor de door hun gemaakte of nog te maken kosten ook in eigen naam geldend maken. De wetgever heeft niet voorzien in een rangorde tussen de primair benadeelde en derde. Het zou interessant zijn te weten of dit in de praktijk tot complicaties leidt.

Afgezien van dit formele punt moet onze aandacht uitgaan naar de 'zelfstandige' schade van derden: daarvoor hebben ze geen verhaalsmogelijkheden jegens de schadeveroorzaker. Het gaat dan niet alleen om naasten, maar ook om contractspartijen, de werkgever, opdrachtgevers, enzovoort. Ik noemde daarvan al voorbeelden. Dit betreft vooral de (potentiële) schuldeisers van de primair benadeelde: contractspartijen of partijen met wie hij zonder het schadefeit een contract zou hebben gesloten. Zoals ik aangaf, dwingt het wettelijk systeem mijns inziens niet tot deze - dogmatisch zeer vergaande - conclusie. De enige conclusie waar dat toe dwingt, is dat deze verhaalsrechten zelf niet worden opgerekt, dat wil zeggen dat ze worden ingeroepen voor meer schade of door andere derden dan die in de wet worden genoemd. Kennelijk verkiest de Hoge Raad hier echter de rechtszekerheid boven de 'normale' vorm van rechtsbescherming aan de hand van de algemene technieken, zoals het relativiteitsvereiste (dat bijvoorbeeld in de Duwbak Linda-zaak aan een vordering van derden in de weg stond; zie par. 3.3.7).

Voor deze derden is het genoemde 'hulpperspectief' niet echt aan de orde. Voor schuldeisers van de primair benadeelde bijvoorbeeld of partijen waarmee hij nog in onderhandeling was, behoort personenschade kennelijk tot de 'normale' contractuele risico's, die ze contractueel moeten afdekken. Doen ze dit niet, dan moet dit niet worden 'beloond' met een uitbreiding van de verhaalsmogelijkheden

Aldus Engelhard 2007, p. 8r e.v. en 2008 p. r e.v. 
jegens degene die voor het schadevoorval aansprakelijk is. Onvoldaan gebleven schuldeisers kunnen de schade wellicht ook trachten te verhalen op de primair benadeelde (of diens erfgenamen), maar over het algemeen zal diens niet-nakoming door het schadevoorval niet toerekenbaar zijn. Deze risico's zullen dus wellicht hoofdzakelijk verdisconteerd zijn in de prijzen van diensten en producten. Er wordt zoals gezegd gesproken over een mogelijke wettelijke regeling voor deze derdenschade; ik ben benieuwd of, als het zo ver komt, zo'n regeling toch weer wordt ingestoken vanuit het genoemde 'hulpperspectief' (in de zin dat de wetgever zich bijvoorbeeld richt op inkomensschade bij mantelzorg voorbij het civiele plafond en bedrijfsschade door re-integratiekosten) of dat er dan zal worden voorzien in een regeling voor de 'echt' zelfstandige schade (zoals de genoemde contractschade en voorts bijvoorbeeld inkomensverlies van naasten door zware geestelijke belasting, die wel verband houdt met het letsel van de primair benadeelde, maar zonder dat ze zorgtaken verrichten die tot die belasting leidt).

Een vraag die hier steeds aandacht verdient, met of zonder 'hulpperspectief', is aan wie het vorderingsrecht (alsmede de actie) toekomt. Een zelfstandige actiemogelijkheid heeft het risico van misbruik of onvoorzienbare nadelige consequenties, waardoor de primair benadeelde de zorg van de naaste die reeds vergoeding heeft ontvangen alsnog zou kunnen mislopen. ${ }^{79}$ De thans geldende regeling, waarin derden (terecht) 'vrij' kunnen beschikken over het vorderingsrecht voor hun eigen schade, heeft ook als het om 'hulpkosten' gaat mijn voorkeur en leidt naar mijn weten ook niet veelvuldig tot moeilijkheden. Maar dit vraagt, zeker als het systeem wordt gewijzigd, om nadere studie.

\subsection{Derdenschade die verband houdt met zaken (objecten) van de primair benadeelde}

\subsubsection{Overzicht}

Hoe verhouden deze uitgangspunten zich tot het vergoedingsregime voor derdenschade die verband houdt met zaakschade van de primair benadeelde? Hierna zal eerst aandacht uitgaan naar de schade die voor rekening komt van de schadeverzekeraar van de eigenaar van de zaak of van hulpdiensten, zoals brandweer of ambulance (paragraaf 3.3.2). Vervolgens wordt aandacht besteed aan de 'eigen', zelfstandige schade van derden-belanghebbenden met feitelijke macht over de zaak, zoals beperkt gerechtigden en houders (paragraaf $3 \cdot 3 \cdot 3$ ), schade van derden met slechts een feitelijk/economisch belang bij de getroffen zaak (paragraaf 3.3.4, 3.3.5 en 3.3.6) en eigenaren van andere zaken (paragraaf $3 \cdot 3 \cdot 7$ ). Daarna wordt ingegaan op een bespreking van een wat specifieker gevalstype, de vorderingen naar aanleiding van kabel- of leidingschade (paragraaf 3.3 .8 en 3.3.9). Besloten wordt met een vergelijking met de verhaalsmogelijkheden bij letselschade (paragraaf 3.3.I0).

79 Van Dam 2007, p. 74 e.v. bespreekt interessante oplossingen onder het Engelse (en Duitse) recht, die voor de Nederlandse situatie nadere studie verdienen. 


\subsubsection{Geldt ook hier het 'hulpperspectief'?}

Schadeverzekeraars die in verband met zaakschade uitkering doen, treden in zoverre, net als bij personenschade, in het recht op schadevergoeding dat de verzekerde heeft jegens de aansprakelijke. Hun verhaalsmogelijkheden zijn dan, door subrogatie, op dezelfde wijze beperkt. Dit past goed bij het hiervoor aangedragen 'hulpperspectief': derden worden niet als benadeelde gezien, maar veeleer als hulpverstrekkers of schadedragers van de primair benadeelde. Het is diens schade die centraal staat. ${ }^{80}$

Weliswaar kunnen schadeverzekeraars bij zaakschade, anders dan bij personenschade, ook zelf een rechtstreeks beroep doen op het aansprakelijkheidsrecht, maar het relativiteitsverweer staat aan het slagen van die vordering in de weg, althans dat deed het in het Brandstichting-arrest. ${ }^{8 \mathrm{I}}$ In die zaak had de (mee)verzekerde echtgenote Vonk brand gesticht, waarna de brandverzekeraar tot uitkering was gehouden van de verzekeringsgelden aan haar echtgenoot, de verzekeringnemer. Van subrogatie was geen sprake aangezien het echtpaar in gemeenschap van goederen was gehuwd (waarbinnen de man dus geen vordering had jegens zijn vrouw). Wel trachtte de verzekeraar de verschuldigde bedragen te verrekenen met een eigen, rechtstreekse vordering uit onrechtmatige daad op de huwelijksgemeenschap. De geschonden strafbepalingen strekten echter niet tot bescherming van het belang van de verzekeraar bij het moeten doen van een uitkering op basis van de verzekeringspolis. Volgens de Hoge Raad zou de brandstichting, behalve tegen de man, tegen de verzekeraar slechts dan onrechtmatig zijn geweest indien het de bedoeling zou zijn geweest de verzekeraar te benadelen.

Dit arrest heeft tot overwegend kritische reacties geleid. Langemeijer stelt dat strafbepalingen die het veroorzaken van personen- of zaakschade sanctioneren 'logischerwijze' op de gedachte berusten dat alle beschadiging of vernietiging van goederen noodwendig iemands belang betreft, al kan men tevoren niet weten wie dat concreet is. Ze strekken tot bescherming van degene die dit blijkt te zijn, of dit nu de eigenaar, huurder of (brand)verzekeraar is. ${ }^{82}$ Dat de Hoge Raad anders heeft beslist, wordt in verband gebracht met het feit dat de verzekeraar in zijn verhouding tot de primair benadeelde nadrukkelijk dit specifieke risico op zich heeft genomen. ${ }^{8}$ Beslissend is dan de aard van de rechtsbetrekking tussen de derde en de primair benadeelde, waarbij op de derde dezelfde verplichting rust als die, zonder zijn tussenkomst, op de aansprakelijke zou rusten. Die verklaart dat hij wordt gesubrogeerd, maar tevens dat hij (buiten dat verhaalsrecht) geen rechtstreekse bescherming aan het aansprakelijkheidsrecht kan ontlenen.

Uitgaande van deze uitleg van het Brandstichting-arrest lijkt het relativiteitsvereiste tevens in de weg te (kunnen) staan aan een rechtstreekse schadevordering van

\footnotetext{
8o Artikel 7:962 BW; vgl. bijvoorbeeld HR 4 maart I955, NJ I955, 30I, Gebroken spiegelruit.

8I HR 24 januari I930, NJ I930, I055, m.nt. EMM, Brandstichting.

82 G.E. Langemeijer, 'De practische beteekenis van de relativiteit der onrechtmatige daad', NJB I940, p. 385-396, p. 39I.

83 Zie uitvoeriger Engelhard 2003, p. 378.
} 
hulpdiensten die verhaal zoeken voor de kosten van bijvoorbeeld een omleiding van de weg of afdamming van een sloot door zaakschade. In het Rijksweg 12-arrest werd vergoeding echter wél mogelijk geacht voor de Staat, die maatregelen moest treffen tot afdamming van een sloot en omleiding van het verkeer: de geschonden norm van het Rijksreglement, die tot zorgvuldig rijgedrag verplichtte, strekte ook tot bescherming van de daarmee gemoeide kosten van de Staat, ook al berustte dat optreden op de publieke beheers- en onderhoudstaak. ${ }^{8}$ Bekend zijn verder de kwesties uit de jaren negentig over het algemeen kostenverhaal door de overheid in verband met saneringskosten bij grondverontreiniging. ${ }^{85}$ Voor kostenverhaal waarvoor een wettelijke grondslag ontbreekt, geldt de 'tweewegenleer' indien dit kosten betreft die met het ingrijpen in het kader van het algemeen belang zijn gemoeid, zoals politiekosten. Ik laat dit aspect hier verder rusten en wijs slechts op de politieke dimensie die dan een rol speelt: het concrete optreden van de Staat wordt uiteindelijk bekostigd van gemeenschapsgeld en wordt, anders dan het optreden van de schadeverzekeraar, aangemerkt als een vorm van (directe) publieke belangenbehartiging.

\subsubsection{Schade van derden met absolute offeitelijke macht over de zaak}

Hoe zijn de verhaalsmogelijkheden voor derden die in een bijzondere rechtsbetrekking staan tot de zaak? Voor beperkt gerechtigden zijn die nog het minst problematisch; zij zijn immers bij een inbreuk op hun absolute recht 'primair gerechtigde', net als de eigenaar (wat impliceert dat ze geen 'derde' zijn). Voor vruchtgebruikers en zekerheidsgerechtigden is bepaald dat hun absolute recht door zaaksvervanging op de vordering tot schadevergoeding komt te rusten. ${ }^{86}$ Andere derden met feitelijke macht over de zaak, bijvoorbeeld huurders, zijn eveneens tot schadevergoeding gerechtigd voor zover de schade hun concreet ten deel valt. ${ }^{87}$ Afhankelijk van de omstandigheden kan ook de eigenaar in sommige gevallen als derde worden aangemerkt, namelijk als hij (ook) zelf in zijn contractuele verhouding tot de beperkt gerechtigde gehouden is om bij beschadiging van de zaak de eventuele herstelkosten voor zijn rekening te nemen.

Afgezien van de positie van de beperkt gerechtigden lijkt het primaat voor het instellen van de vordering in deze gevallen echter wel bij hem, de eigenaar, te worden gelegd, ten minste waar het de herstelkosten en het gebruiksgenot betreft. De eigenaar zou dan, naast of in plaats van een bezitsactie, schadevergoeding kunnen

84 HR I9 december I975, NJ I976, 280, m.nt. GJS, Rijksweg 12. De Staat had geen concrete kosten gemaakt; de schade bestond uit het niet voor andere doeleinden over het desbetreffende personeel kunnen beschikken en ingezet materieel.

85 Zie in het kader van het relativiteitsvereiste m.n. HR 9 februari I990, NJ I99I, 462, m.nt. CJHB, Staat v. Van Amersfoort; HR 24 april 1992, NJ 1993, 643, Van Wijngaarden v. Staat en NJ I993, 644, m.nt. CJHB, Staat v. Akzo; HR 30 september I994, NJ I996, I99, m.nt. CJHB, Van den Brink v. Staat.

86 Die zij dan inningsbevoegd, evtueel naar rato van de waardevermindering, zie artikel 3:2 I3 lid I BW (bij vruchtgebruik) en artikel 3:229 lid I BW (bij pand of hypotheek). Zie J. De Bie Leuveling Tjeenk, Gerechtigden tot schadevergoeding bij zaakschade, Deventer: Kluwer, I997, p. 2II e.v.

87 Rb. Breda 2 juni I995, VR I960, 45; Hof 's-Gravenhage 17 december I99I en 23 november I993, S\&S I994, 27, W.D. Riversland v. Summersea, r.o. Io, aangehaald bij De Bie Leuveling Tjeenk I997, nt. 26. 
vorderen voor de inbreuk op zijn eigendomsrecht, zowel met betrekking tot de reparatiekosten (of bij vernietiging van de zaak de waardevermindering) als voor gederfd gebruiksgenot en/of eventuele huurderving. ${ }^{88}$ Hier lijkt niet aan in de weg te staan dat de zaak in handen is van de derden. Er zijn althans uitspraken waarin is aangenomen dat de schadeveroorzaker zich in dat geval jegens de eigenaar niet kan verweren met de stelling dat die zich maar op de houder moet verhalen. ${ }^{89}$

\subsubsection{Kopers die de koopprijs nog niet hebben voldaan: herstelkosten}

Dat er om formele redenen terughoudend wordt omgegaan met vorderingen voor (mogelijk) dezelfde schade, zien we ook bij derden met een zuiver economisch belang bij de zaak, te weten kopers aan wie de zaak is verkocht, maar nog niet overgedragen. Die hebben - zolang ze de koopprijs nog niet hebben voldaan - geen recht op schadevergoeding, hoewel er enkele uitspraken zijn die wél in die richting wijzen. ${ }^{90}$ De Bie Leuveling Tjeenk is daar in zijn dissertatie kritisch over. Hij noemt het bezwaarlijk de koper al een rechtstreekse aanspraak op schadevergoeding toe te kennen omdat dan in feite - zolang de koopprijs nog niet is voldaan - de verkoper het financiële risico draagt. Daarom zou het uitsluitend de eigenaar moeten zijn, die het recht heeft op schadevergoeding op de grond dat zijn eigendom beschadigd is. De verkoper zou schade lijden doordat zijn eigendom is beschadigd, zelfs als het risico reeds op de koper is overgegaan. Uitsluitend hem, de eigenaar, zou daarom het recht toekomen om een vordering tot schadevergoeding uit onrechtmatige daad in te stellen. ${ }^{91}$

Volgens mij betreft deze discussie uitsluitend de vraag aan wie de vordering toekomt en staat de materiële aanspraak van de koper niet ter discussie, althans niet voor wat betreft zijn aanspraak op vergoeding van herstelkosten en gebruiksderving. Zo zou de verkoper, zodra hij alsnog betaling van de koopprijs ontvangt, uit hoofde van artikel 6:78 BW gehouden zijn om de geïnde schadevergoeding af te dragen aan de koper, of als hij de schadeveroorzaker nog niet heeft aangesproken, zijn vordering aan de koper over te dragen. ${ }^{22}$ Terughoudender lijkt te worden omgegaan met de materiële aanspraak voor 'eigen' schade, bijvoorbeeld contractuele gevolgschade, tenzij de veroorzaker van de initiële schade het oogmerk heeft gehad om (ook) hun te benadelen. ${ }^{93}$ Tot die vormen van derdenschade zal ik me hierna beperken.

88 Hof 's-Gravenhage I7 december I99I en 23 november I993, S\&S I994, 27, W.D. Riversland $v$. Summer Sea, r.o. I2, aangehaald bij De Bie Leuveling Tjeenk I997, p. 204.

89 Rb. Rotterdam I7 augustus I995, S\&S I996, II4, Andrév. Jan Senior en Polaris.

90 Zie Hof Amsterdam 20 juli I961, S\&S I962, II en Hof's-Gravenhage 2I oktober I964, S\&S I966, I2, aangehaald bij De Bie Leuveling Tjeenk I997, p. 235.

9I Hof's-Gravenhage 2I september 1978, NJ I979, I23; Bloembergen I965, nr. I75; De Bie Leuveling Tjeenk I997, p. 2 Io.

92 Artikel 6:78 lid 2 BW, De Bie Leuveling Tjeenk I997, p. 2 Io.

93 De Bie Leuveling Tjeenk I997, p. 234-235. Een 'uitzondering' geldt bij medeaansprakelijkheid: C (derde) heeft verhaal op de andere aansprakelijke A (de feitelijke schadeveroorzaker) voor zover $\mathrm{C}$ de zaakschade van $\mathrm{B}$ heeft vergoed. 


\subsubsection{Zuiver economische belangen en 'eigen' contractschade: afnemers}

Voor contractspartijen zonder feitelijke of absolute macht over de zaak lijkt dan vrij algemeen te worden aangenomen dat ze jegens de schadeveroorzaker geen recht op schadevergoeding hebben. Illustratief is een uitspraak aan van de Rechtbank Roermond: een afnemer van broedeieren ziet zijn recht op levering verstoord raken doordat de kuikens van de leverancier door mestdampen van een naburig gelegen kwekerij zijn vergiftigd. Hij vordert van de kwekerij het verschil tussen de (zeer gunstige) contractsprijs en de prijs die aan een nieuwe leverancier moet worden betaald. ${ }^{94}$ Volgens de rechtbank beroept de kwekerij, die aan de leverancier de initiële schade van de kuikens zelf heeft vergoed, zich jegens de afnemer met succes op ontbrekende relativiteit/onzorgvuldigheid: de afnemer kan met betrekking tot de kuikens geen absoluut recht doen gelden, en de kwekerij behoeft niet te rekenen met contractspartijen van zijn buren, voor zover die hem niet bekend zijn geweest.

De afnemer heeft zich 'nu eenmaal' zelf van de leverancier afhankelijk gemaakt en had het bedrijfsrisico maar contractueel met de leverancier moeten regelen. De schadeveroorzaker heeft de nadelige gevolgen daarentegen slechts in zeer beperkte mate kunnen voorkomen, 'zeker ten opzichte van de middellijk belanghebbenden', zoals de afnemer. 95

\subsubsection{Zuiver economische belangen en 'eigen' contractschade: huurders}

Ook voor andere derden met een puur contractueel belang bij de getroffen zaak lijken de verhaalsmogelijkheden jegens de schadeveroorzaker niet sterk. Zo hebben huurders die het door hun gehuurde pand nog niet feitelijk hebben betrokken, bij brand in beginsel geen aanspraak op schadevergoeding voor de hotelkosten die ze maken ter overbrugging van de herstelperiode als ze hun oude woning al hebben verkocht. ${ }^{6} \mathrm{Zij}$ moeten het eveneens stellen met hun contractuele aanspraak jegens de verhuurder.

Al met al lijkt het erop dat voor de vergoeding van 'zelfstandige' schade vaak de grens ligt bij derden die geen absoluut recht of feitelijke macht toekomt, en uitsluitend een contractueel belang hebben bij de zaak. Zij kunnen, uitzonderingen daargelaten, slechts verhaal zoeken bij de eigenaar of zakelijk gerechtigde.

\subsubsection{Andere zaakseigenaren}

Het voorgaande ging steeds over derden die in een bijzondere relatie stonden tot de beschadigde zaak, maar bij 'zelfstandige' derdenschade kan natuurlijk vooral worden gedacht aan eigenaren of derden die door de zaakschade zelf schade ondervinden aan (bijvoorbeeld aan hun toebehorende) andere zaken. Denk aan de schade

94 Rb. Roermond 8 oktober I98I, NJ I983, II7, Plumex v. CNC.

95 Vgl. ook HR 27 januari I984, NJ I984, 536, m.nt. G, Verstekeling.

96 Hof 's-Gravenhage $\mathrm{I}_{3}$ november I952, NJ I953, 664, aangehaald bij De Bie Leuveling Tjeenk I997, p. 236. 
van omwonenden of medeweggebruikers bij een overslaande brand of een kettingbotsing. Deze derden hebben ook een zelfstandige vordering uit hoofde van artikel 6:I62 BW, zonder bijzondere restricties. In het Duwbak Linda-arrest is de Hoge Raad weliswaar terughoudend ten aanzien van de eigenaar van een nabij gelegen vaartuig die zaakschade heeft ondervonden van het kapseizen van een duwbak, maar cruciaal voor dat arrest lijkt dat de keuringsinstantie en de Staat hiervoor werden aangesproken in verband met een ten onrechte aan de eigenaar van de duwbak afgegeven keuringscertificaat. Zo'n certificaat strekt niet tot bescherming van een onbepaalde groep derden die daar schade van ondervindt. De verklaring van dit arrest ligt dan ook niet zozeer bij de problematiek van de afbakening van derdenschade, doch veeleer bij de afbakening van de kring van aangesproken derden: keuringsinstanties en de toezichthouder. ${ }^{97}$

\subsubsection{Derdenschade door leiding- en kabelschade ('cable cases')}

Een belangrijke uitzondering op deze uitsluiting van derden met zuiver contractuele belangen met betrekking tot de beschadigde zaak, zien we bij de cable cases. Kabel- of leidingschade veroorzaakt door fouten bij graafwerkzaamheden,,$^{98}$ of bijvoorbeeld brandstichting, treft typisch afnemers. Voor zover dit tevens de eigenaar van de beschadigde kabel of leiding is, wordt aangenomen dat sprake is van een inbreuk op een recht in de zin van artikel 6:162 BW. ${ }^{99}$ Maar kunnen afnemers of gebruikers die zelf geen zakelijk gerechtigde van de beschadigde leiding zijn, en slechts afhankelijk zijn van de kabel-/leidingtoevoer, de schadeveroorzaker aanspreken tot schadevergoeding?

De standaardarresten hierover zijn al wat ouder, maar ik bespreek er één omdat het me, voor zover het althans nog geldend recht is (zie hierna), wel instructief lijkt voor wat betreft de technieken en discussies. De steenfabriek Esbeek ondervond een gasonderbreking doordat tijdens graafwerkzaamheden van Van Hees met een dragline een aardgastransportleiding was geraakt waarvan Esbeek als gasafnemer afhankelijk was. Esbeek vordert vergoeding van de ontstane bedrijfsstagnatie. ${ }^{100}$ In cassatie wordt ervan uitgegaan dat de draglinemachinist heeft nagelaten om eerst de tekening van het verloop van de leiding te zien, alvorens te graven. Zoals bekend rust er op gravers in dit verband een strenge onderzoeksplicht om te voorzien dat er op de plaats van werkzaamheden mogelijk een kabel loopt. Die voorzienbaarheid pleegt, gelet op de hoge kabel- en leidingdichtheid in Nederland, gauw te worden aangenomen. ${ }^{\text {ror }}$ Als de tekeningen van de precieze locatie niet zijn geraadpleegd,

97 HR 7 mei 2004, NJ 2006, 28I, m.nt. Jac. Hijma, Duwbak Linda.

98 De 'wenk' van RVR 20I0, 33 vermeldt zo'n 40.000 incidenten per jaar door graafwerkzaamheden.

99 Aldus Hof Arnhem 17 augustus 20I0, LJN BN3795, Alliander v. Vink Aannemingsmaatschappij, r.o. 4.3, waar overigens in hoger beroep naar voren kwam dat de eiser het vorderingsrecht van de eigenaar door cessie had verkregen.

Ioo HR I juli I977, NJ I978, 84, m.nt. GJS, Van Hees v. Esbeek.

IOI O.a. HR 2 oktober I998, NJ I998, 83I, Nacap v. International Shellfish, Hof Den Haag 30 juni 2009, LJN BJ4217, Ballast Nedam v. Alliander en Rb. Zutphen 23 december 2009, NJF 2010, 91, ook in RVR 20Io, 33, Kab Accountants v. Nipcon c.s. 
lijkt schuld, zeker waar het bijvoorbeeld een toegangsweg naar een industrieterrein betreft, al gauw gegeven; men moet al het mogelijke hebben gedaan om kabels te lokaliseren. ${ }^{\text {I02 }}$ De graver kan dan doorgaans slechts nog de relativiteit en/of causaliteit betwisten.

De graafonderneming verweerde zich met de stelling dat uitsluitend 'rechthebbenden op een beschadigde zaak' (hier: de exploitant) recht hebben op vergoeding 'en niet degenen die - zoals Esbeek - wel belang hebben bij ten algemene nutte strekkende voorwerpen maar geen subjectieve rechten daarop kunnen doen gelden'. Maar dit relativiteitsverweer slaagt niet. 'Niet juist' noemt de Hoge Raad de stelling dat het belang van Esbeek bij een ongestoorde energievoorziening niet zou worden beschermd door de geschonden gedragnorm. Die norm geldt juist met het oog op zulke belangen. Hetzelfde werd recenter in de lagere rechtspraak beslist ten aanzien van het (eveneens tweedegraads) belang bij ongestoord dataverkeer. ${ }^{103}$ Daarnaast betwistte het graafbedrijf tevergeefs de causaliteit: de schade zou mede zijn veroorzaakt door de afhankelijkheid van de gasvoorziening voor de bedrijfsvoering. De schade zou daarom niet (volledig) mogen worden toegerekend. Ook hierin ziet de Hoge Raad geen beletsel voor het aannemen van aansprakelijkheid. De afhankelijkheid maakt het causale verband kennelijk juist sterker. Wel wijst de Hoge Raad erop dat niet is aangevoerd dat Esbeek met het oog daarop ook zelf maatregelen had moeten treffen. Recenter werd echter ook een eigenschuldverweer jegens de tweedegraads afnemer, dat erop neerkwam dat die zelf niet in een reserveleiding had voorzien, verworpen. ${ }^{\text {I04 }}$

Ten slotte beklaagt graafbedrijf Van Hees zich tevergeefs over de 'vanuit maatschappelijk oogpunt verstrekkende gevolgen van een zo omvangrijke aansprakelijkheid voor gedragingen als die van [haar draglinemachinist, EE]'. De Hoge Raad oordeelt dat het risico 'dat aldus voor hen die voor de gemaakte fout aansprakelijk zijn, een grote uitgebreidheid van vergoedingsplichten zou kunnen ontstaan' (het floodgates-risico) niet aan het recht op schadevergoeding in de weg staat. In dit verband wordt ook gewezen op het risico van een oncontroleerbaar aantal schadevorderingen of onverzekerbaarheid en aan de vraag wie de meest 'efficiënte' partij is om dit risico te verzekeren: dat zou in het algemeen eerder de eigenaar of de afnemer zijn dan de graver. ${ }^{105}$

Dit risico lijkt er door de enorme technologische ontwikkelingen van communicatiemiddelen en de digitalisering van signalen die in de ruim dertig jaar sinds het verschijnen van dit arrest heeft plaatsgevonden, niet kleiner op geworden. Integendeel, de samenleving wordt steeds afhankelijker van technologieën die netwerken

I02 Ook onder het zgn. Klicsysteem, vgl. HR 2 oktober I998, NJ I998, 83I, Nacap v. International Shellfish. Doch zie daarbuiten bijvoorbeeld Hof Arnhem I7 augustus 20I0, LJN BN3795, Alliander v. Vink Aannemingsmaatschappij, r.o. 4.7 e.v.

I03 Rb. Zutphen 23 december 2009, NJF 2010, 9I, ook gepubliceerd in RVR 2010, 33, Kab Accountants $v$. Nipcon c.s., r.o. 5.7.

I04 Rb. Zutphen 23 december 2009, NJF 20I0, 9I, ook gepubliceerd in RVR 2010, 33, Kab Accountants $v$. Nipcon c.s., r.o. 5.I2.

I05 Hartlief 2006, p. Ioo; vgl. ook B.S. Markesinis \& H. Umberath, The German Law of Torts, A Comparative Treatise, Oxford: Hart, 2002, p. 203 e.v. 
van mensen met elkaar in verbinding brengen, waardoor in elk geval de schadeketen zelf langer lijkt te worden. Denk aan vorderingen van opdrachtnemers die tijdelijk geen declarabele werkzaamheden kunnen uitvoeren door het uitvallen van de aansluitkabel waarin glasvezelkabels liggen ten behoeve van een bepaalde datalijnverbinding. ${ }^{106}$ Of aan het uitvallen van de computer van een serviceprovider, met de schade van alle daarop aangesloten internetgebruikers en hun afnemers tot gevolg. Of aan het uitvallen van een centraal opstelpunt, zoals een zendmast, waardoor tientallen particulieren tijdelijk niet kunnen bellen. In hoeverre zulke risico's van vermogensschade thans langs andere weg worden afgekaart, lijkt onduidelijk maar dat daar aantoonbaar schade blijft liggen lijkt wel zeker. Bovendien is het niet uitgesloten dat gebruikers niet (alleen) hun provider, maar bijvoorbeeld bij de telefonie (ook) het netwerkcoördinatiepunt aanspreken op de grond dat dit niet tijdig of inadequaat heeft ingegrepen (bijvoorbeeld indien men de storing had moeten voorzien).

Op basis van Van Hees v. Esbeek, en het eerdere Spitfire-arrest, ${ }^{107}$ wordt echter aangenomen dat kabelvorderingen het meest kansrijk zijn in de 'tweede graad'. Hoewel de Hoge Raad niet spreekt in termen van schadegraden, wordt de grens dus gelegd bij directe energieafnemers, zoals Esbeek. Zeer in het algemeen gesteld leveren de vereisten van relativiteit en causaliteit voor die schadeschakels geen bijzondere moeilijkheden op. ${ }^{\text {108 }}$ Derdegraads- en volgende schade valt in beginsel buiten de bescherming van de geschonden norm en/of wordt causaal niet toegerekend. ${ }^{109}$

\subsection{9 'Hulpperspectief' bij kabelexploitant die de schade aan de afnemer vergoedt}

Ten slotte verdient hier nog het geval vermelding waarin de eigenaar van de kabel, na de beschadiging daarvan door een ander, ook zelf (mede)aansprakelijk is. In feite kan de schade die hij dan als hoofdelijk aansprakelijke op zich neemt en waarvoor hij verhaal zoekt bij de medeschuldenaar, ook 'derdenschade' worden genoemd. Aangezien de interne positie van medeschuldenaren te veel bespreking vergt, heb ik ervoor gekozen die in dit preadvies niet te bespreken. Ik stip het alleen aan omdat ook hier op een zeker 'hulpperspectief' kan worden gewezen, wanneer de netbeheerder bijvoorbeeld de aannemer tot verhaal aanspreekt voor de compensatievergoedingen die hij bij kabelschade aan afnemers verschuldigd is. Die vorderingen lijken doorgaans, binnen de algemene grenzen van het aansprakelijkheidsrecht, wel te worden toegewezen. ${ }^{\text {IIo }}$

Dit voorbeeld kent vele varianten. Ik wijs ter illustratie op een arrest van het Hof Den Bosch, dat betrekking had op saneringskosten bij grondverontreiniging. ${ }^{\text {II }}$ De

Io6 Vgl. bijvoorbeeld Rb. Zutphen 23 december 2009, NJF 20I0, 9I, ook gepubliceerd in RVR 20I0, 33, Kab Accountants v. Nipcon c.s.

I07 HR I4 maart I958, NJ I96I, 570, Spitfire, zie reeds Köster I963, p. I7 en Bloembergen I965, p. 279.

Io8 Köster I963, p. I7, R.J.P. Kottenhagen, 'Over bris de cables, kabelbruchfälle en cable cases', Bouwrecht I992, p. 653-672, De Bie Leuveling Tjeenk I997, p. 202.

Io9 Zie daarover Scholten in zijn NJ-noot, doch met verwijzingen naar andersluidende opvattingen.

IIO Hof Arnhem I6 maart 20I0, LJN BL8028, Liander v. Bouwcombinatie c.s.

III Hof Den Haag 30 juni 2006, LJN BJ4217, Ballast Nedam Infra v. Alliander. 
aanleiding voor deze kwestie was de verplichting die de Wet bodembescherming legt op degenen die handelingen met de bodem verrichten, wetend dat de bodem door die handelingen is verontreinigd, om de bodem te saneren of de aantasting en de directe gevolgen daarvan te beperken en zo veel mogelijk ongedaan te maken. Nutsbedrijf Nuon had op die grond saneringskosten gemaakt ten behoeve van de provincie, die grondeigenaar was en zocht verhaal bij het graafbedrijf dat de kabel had beschadigd. Deze vordering slaagde; Nuon zelf viel namelijk volgens het hof niets van de beschadiging van de kabel en de afwikkeling nadien te verwijten. Maar ook buiten het terrein van kabelschade zijn vele variaties mogelijk. Denk bijvoorbeeld aan de 'schade' van de aanbieder van een achteraf ondeugdelijk effectenleaseproduct, die voor de door hem aan de lessee verschuldigde bedragen een vergoeding vraagt van de cliëntenremissier. ${ }^{112}$ Het voert voor dit preadvies te ver om daar verder op in te gaan.

\subsubsection{Evaluatie en vergelijking met derdenschade door letsel}

Het belangrijkste punt dat uit de voorgaande analyse naar voren komt, is dat er bij zaakschade dus sprake lijkt van eenzelfde terughoudende benadering ten aanzien van schade die buiten de schade van de primair benadeelde (de eigenaar) valt als bij personenschade. Voorop staat dat gevalsvergelijkingen hier natuurlijk worden bemoeilijkt door grote feitelijke verschillen met betrekking tot de casuïstiek. Zo wordt er bij zaakschade meer dan één partij als 'primair benadeelde' aangemerkt, namelijk niet alleen de eigenaar van de zaak, maar alle absoluut gerechtigden (ook beperkt gerechtigden). Voor de afbakeningsproblematiek lijkt dit prima facie misschien een essentieel verschil, zeker met het oog op hoe sterk bij shockschadeclaims van derden wordt ingezet op het bemachtigen van de kwalificatie van 'primair benadeelde' (om te ontsnappen aan het restrictieve gesloten vergoedingssysteem bij personenschade). Maar daar ligt een belangrijk verschil: de ruime kring van primair benadeelden heeft immers niets te maken met de afbakening van de verhaalsmogelijkheden; die volgt noodzakelijkerwijs uit het absolute karakter van het eigendomsrecht en de beperkte rechten. De wijze waarop met de positie van derden wordt omgegaan, leent zich dus goed voor een vergelijking, ook al is de kring van primair benadeelden bij zaakschade ruimer dan bij personenschade.

Net als bij personenschade zien we dan een sterk ' hulpperspectief': schadeverzekeraars bijvoorbeeld hebben alleen een verhaalsrecht voor de schade-uitkeringen die ze betalen aan de primair benadeelde: ze verkrijgen niet méér dan hetgeen de schadeveroorzaker aan de primair benadeelde verschuldigd zou zijn geweest. De schadeverzekeraar wordt helemaal niet gezien als 'zelfstandig' benadeelde; bij een eigen, rechtstreeks beroep op het aansprakelijkheidsrecht lijkt veelal te moeten worden aangenomen dat de relativiteit ontbreekt. Ook waar het om andere derden gaat zien we deze benadering terug: derden hebben bovendien wel recht op vergoeding

II2 Maar de gebrekkige voorlichting van de remissier aan de cliënt kwam voort uit de gebrekkige informatievoorziening van de aanbieder en mocht daarom niet via een regresactie van de laatste op de eerste worden afgewenteld, Rb. Dordrecht I4 april 20Io, LJN BMI836, Defam v. Asskredon. 
van de herstelkosten, maar het primaat voor het instellen van de vordering ligt dan bij de eigenaar. Voor 'zelfstandige' schade (dat wil zeggen: andere schade van derden dan de schade die voor rekening van de eigenaar zou zijn gekomen/gebleven als de zaak niet in hun handen was geraakt) wordt men niet beschermd: zuiver contractueel belanghebbenden hebben, net als bijvoorbeeld geldt voor naasten met inkomensschade en voor werkgevers met bedrijfsschade, geen recht op schadevergoeding voor hun zuivere vermogensschade.

De terughoudendheid zit dus in beide gevallen niet zozeer in het feit dat er schade wordt geleden in een zuiver financieel belang, maar dat er schade wordt geleden in een belang dat niet is te herleiden tot de schade die, zonder tussenkomst van de derde, de primair benadeelde ten beurt zou zijn gevallen. Dit betreft hoofdzakelijk contractuele schade en bedrijfsrisico's; die moet men kennelijk contractueel ondervangen, in de verhouding tot de primair benadeelde door het afsluiten van een verzekering, of via doorberekening in de prijzen van producten en diensten.

Het voorgaande behoeft op drie punten nuancering. Ten eerst werd hiervoor gezien dat ook zelfstandige schade van hulpdiensten voor vergoeding in aanmerking komt, anders dan bijvoorbeeld het geval is voor bedrijfsschade van de werkgever van een werknemer met letselschade. Bovendien zagen we dat derdenschade die het gevolg is van kabel- of leidingschade voor schadevergoeding in aanmerking komt (zij het - vermoedelijk - niet bij schade in de derde graad). Ten derde behoeft de vergelijking met letselschade nuancering voor wat betreft de 'formele' rangorde van de vorderingen van de derden en de primair benadeelde zelf jegens de schadeveroorzaker. Voor anderen dan de verzekeraar of absoluut gerechtigden wordt er gepleit voor kanalisatie naar de eigenaar: bij hem ligt het primaat voor het instellen van de vordering. Wat de wettelijke basis hiervoor is, werd niet duidelijk.

\subsection{Schade van aandeelhouders door aantasting van het vennootschapsvermogen}

\subsubsection{Overzicht; risicoperspectief?}

Hiervoor was derdenschade het gevolg van schade aan de persoon of aan zaken van de primair benadeelde. Dat ook schade in het vermogen zo'n domino-effect heeft, behoeft bij het huidige economische klimaat weinig toelichting, al zal dit slechts bij een fractie van het 'financieel leed' waarvoor vergoeding wordt gevorderd om 'derdenschade' gaan. Daarvoor is immers een verbondenheid nodig tussen de derde en de eerst benadeelde. Anders dan bij zaken of personen kan een automobilist niet met een vermogen in botsing raken. Bij derdenschade door vermogensnadeel van de vorige schakel gaat het dan ook veeleer om, voorafgaand aan het schadegebeuren, gelegde verbindingen, veelal door het sluiten van contracten. Zuiver conjuncturele schommelingen maken nog geen 'derdenschade', zoals ik deze term in de inleiding heb gedefinieerd. We zien dan eerder argumenten als dat de derde 'beter' hadden moeten weten: het schaderisico werd 'bewust' aangegaan, kortom een 'risicoperspectief'. 
Tegen die achtergrond zullen verhaalsmogelijkheden worden besproken voor aandeelhouders wier aandelen in waarde zijn verminderd als gevolg van de aantasting van het vermogen van de vennootschap. In paragraaf 3.5 komt de uitbreiding van de verhaalsmogelijkheden aan bod voor schuldeisers met afgeleide schade.

\subsection{2 'Afgeleide schade' versus 'rechtstreekse schade'}

De vordering tot schadevergoeding van aandeelhouders kan gericht zijn tegen bestuurders, commissarissen of andere derden, zoals kredietverstrekkers die wordt verweten dat ze de vennootschap hebben benadeeld. Het is in deze gevallen dus primair de vennootschap die schade lijdt en pas door de vermindering van het vennootschapsvermogen ontstaat de schade van de aandeelhouders. Dit wordt, ook door de Hoge Raad, 'afgeleide schade' genoemd. ${ }^{113}$ Wat preciezer wordt deze term omschreven als grofweg de schade die de vennootschap heeft geleden gedeeld door het aantal geplaatste aandelen. ${ }^{\mathrm{II}}$ Hieruit blijkt dat het om een zeer specifieke toepassing van derdenschade gaat. In paragraaf 3.5.5 zal ik aan de hand van een ander geval van derdenschade laten zien dat 'afgeleide schade' en 'derdenschade' niet helemaal eenop-een gaan. De bijzondere beperkingen voor aandeelhouders die hierna worden besproken, hebben echter betrekking op 'afgeleide schade' in de zojuist genoemde technische betekenis.

Tegenover 'afgeleide schade' staat 'rechtstreekse schade' van aandeelhouders, waaronder dan de waardevermindering van aandelen wordt verstaan die qua hoogte uitsluitend wordt bepaald door fluctuaties op de beurs of in het economisch verkeer, dus zonder direct verband met vooraf aan de vennootschap toegebrachte schade. Daartoe worden ook de gevallen gerekend dat het bestuur ten onrechte optimistische verwachtingen over de winst uitspreekt, op basis waarvan aandelen tegen een daardoor, naar later blijkt, veel te hoge prijs worden gekocht. ${ }^{115}$ Daarbij is er in beginsel geen sprake van afgeleide schade. ${ }^{\text {I16 }}$

Toch laten die gevallen volgens mij ook goed zien hoe subtiel het verschil tussen 'afgeleide' en 'rechtstreekse' schade in feite is. Strikt genomen is er bij misleiding met betrekking tot de winstprognose geen sprake van afgeleide schade, maar die kan geleidelijk wel later in dat proces ontstaan, bijvoorbeeld bij het vooruitzicht

II3 Ook de Hoge Raad gebruikt deze term, zie o.m. HR 29 november 1996, NJ 1997, I78, Cri Cri Geleen.

II4 Zie uitvoerig L. Timmerman, 'Kan een aandeelhouder of vennootschapsschuldeiser afgeleide schade vorderen?', TVVS I998, p. 97-IoI, p. 97 e.v.; M.J. Kroeze, Afgeleide schade en afgeleide actie, Deventer: Kluwer, 2004 , p. 9 e.v.; A.F. Verdam, 'M.J. Kroeze, Afgeleide schade en afgeleide actie verschenen in de serie Uitgaven vanwege het Instituut voor Ondernemingsrecht, Rijksuniversiteit Groningen, 2004', NTBR 2006, p. IOI-Io6.

II5 Van Wijk 2008.

II6 Zie daaromtrent o.m. Asser/Maeijer/Van Solinge \& Nieuwe Weme 2-II^, De naamloze en besloten vennootschap, bewerkt door G. Van Solinge \& M.P. Nieuwe Weme, m.m.v. R.G.J. Nowak, ze druk, Deventer: Kluwer, 2009, nr. 470 sub b en B.J. De Jong, Schade door misleiding op de effectenmark (enz.), Deventer: Kluwer, 20I0, p. 43; vgl. voorts o.a. HR 27 november 2009, LJN BH 2I6I, Vereniging van Effectenbezitters c.s. v. World Online International en inzake Fortis bijvoorbeeld Rb. Den Haag 2I oktober 2009, LJN BKo74I, Eiser v. Staat. 
van de kosten van juridische procedures. Aangezien die het vennootschapsvermogen verminderen, is verdedigbaar dat de koersdaling, voor zover die (mede) daarop berust, aan 'afgeleide schade' gelijk moet worden gesteld. ${ }^{\mathrm{I17}}$ Gevallen van misleiding zullen hier echter verder buiten beschouwing worden gelaten; mijn aandacht ligt bij de gevallen van 'zuiver' afgeleide schade van aandeelhouders.

\subsubsection{Hoofdregel: geen uitbreiding van de aansprakelijkheid naar afgeleide schade}

De verhaalsmogelijkheden voor deze schade zijn ernstig beperkt door de bekende hoofdregel van het Poot $v$. ABP-arrest: de afgeleide schade van aandeelhouders wordt in beginsel niet rechtstreeks beschermd; het is slechts aan de vennootschap om eventueel schadevergoeding te vorderen voor de vermindering die het vennootschapsvermogen door de fout van de schadeveroorzaker heeft ondergaan. ${ }^{\text {Ir8 }}$ Individuele aandeelhouders of de algemene vergadering van aandeelhouders kunnen, individueel of namens de rechtspersoon, ook geen vergoeding vorderen voor de schade van de vennootschap (of dus voor de daaraan gerelateerde waardevermindering van hun aandelen). Dit geldt ongeacht of de aandelen in meerdere handen of slechts in één hand zijn en wanneer dit laatste het geval is, dan doet het evenmin ter zake dat de enig aandeelhouder als directeur het doen en laten van de vennootschap beheerst. Volgens het arrest Heino Krause ${ }^{119}$ geldt deze regel ook voor de leden van een traditionele coöperatie wier inkomsten afhankelijk zijn van het bedrijfsresultaat.

Deze hoofdregel staat de laatste jaren sterker in het kader van de onrechtmatigheidsvraag en staat nog los van de vraag naar causaal verband. ${ }^{120}$ 'Technisch' betekent dit dat benadeling van de vennootschap geen inbreuk oplevert op een subjectief recht van de aandeelhouders (in de zin van artikel 6:I62 lid $2 \mathrm{BW}$ ) en dat voor het aannemen van onrechtmatigheid méér nodig is dan de schending van een zorgplicht jegens de vennootschap. Nodig is de schending van een zorgplicht die specifiek strekt tot bescherming van de aandeelhouder, in persoon. Daarvoor kan de aandeelhouder kortom niet volstaan met het stellen van de wanprestatie of het onzorgvuldig handelen jegens het concern.

\subsubsection{Risico: men steekt privégeld in een afgescheiden vermogen}

De argumenten voor de uitsluiting van aandeelhouders staan in het licht van de visie op de vennootschap als een aparte, zelfstandige, deels van de aandeelhouders onafhankelijke rechtspersoon. Die brengt weliswaar nog niet mee dat er niet óók onrechtmatig jegens individuele aandeelhouders kan worden gehandeld, ${ }^{\mathrm{I} 2 \mathrm{I}}$ maar het punt is dat de vennootschap een gescheiden vermogen heeft en uitsluitend

II7 In die zin De Jong 20I0, p. I9I.

II8 HR 2 december I994, NJ I995, 288, m.nt. Ma, Poot v. ABP.

II9 HR I3 oktober 2000, NJ 2000, 699, m.nt. Ma, Heino Krause.

I20 Hartkamp bespreekt dit in zijn Conclusie voor Poot v. ABP, nr. 9 en acht het leerstuk van het causaal verband ongeschikt vanwege de hoge mate van voorzienbaarheid van de schade voor de aandeelhouder.

I2I Vgl. C.E. du Perron, Overeenkomsten en derden, Deventer: Kluwer, I999, p. 310-318. 
in haar eigen entiteit kan en moet optreden tegen de benadeling daarvan. Met de rechtspersoonlijkheid wordt ook juist beoogd te komen tot een materiële en processuele bundeling van belangen én de behartiging ervan. ${ }^{\mathrm{I} 22}$ De vennootschap heeft verschillende mogelijkheden, zij het beperkter waar dit vorderingen tegen werknemers (en/of bestuurders) betreft. ${ }^{123}$ Als die succesvol zijn, zou er in zoverre ook geen waardevermindering meer hoeven te zijn. De aandeelhouders zouden het bestuur van de vennootschap daartoe kunnen aanzetten. ${ }^{124}$ De sleutel voor de verklaring van de ontbrekende verhaalsmogelijkheden ligt kortom bij de verhouding van het - afgescheiden - vermogen van de vennootschap (primair benadeelde) tot de (privé)vermogens van derden, waartoe ook de aandeelhouders behoren. ${ }^{125} \mathrm{Bij}$ (interne) bestuurdersaansprakelijkheid zou de vordering van de aandeelhouders neerkomen op een betaling uit de vennootschapsboedel naar het privévermogen van de desbetreffende aandeelhouders. Dat zou de instandhouding van het vermogen van de rechtspersoon in gevaar kunnen brengen en daarmee de rechten van allen die daarbij belang hebben. ${ }^{\mathrm{I} 26}$ Het zou ook tot ongelijkheid kunnen leiden tussen de aandeelhouders onderling en een doorkruising kunnen zijn van de in het wettelijk systeem neergelegde rangorde tussen aandeelhouders en schuldeisers. Bij een vordering door de curator zal de te ontvangen schadevergoeding in de boedel belanden en dus ten goede komen aan alle schuldeisers. ${ }^{127}$

Er wordt daarnaast wel gewezen op het risico van een oncontroleerbare toeloop van schadevorderingen en van 'chaotische procestoestanden': individuele aandeelhouders zouden naar rato van hun aandelenbezit zelf schadevergoeding vorderen, hetgeen tot diverse, naast elkaar lopende procedures op basis van hetzelfde feitencomplex zou kunnen leiden met alle mogelijke complicaties van dien. ${ }^{128}$ Maar de uitsluiting kan er vanuit het oogpunt van proceseconomie net zo goed toe leiden dat aandeelhouders de vennootschap zelf zullen aanspreken, die dan op haar beurt weer de schadeveroorzaker in vrijwaring zal willen oproepen, hetgeen allemaal tijd kost en een voor hun onzekere uitkomst heeft. ${ }^{129}$

Het kernargument is dat aandeelhouders hun privégeld steken in een afgescheiden vermogen. Wie dat doet, aandelen houdt in een vennootschap, weet, nog voorafgaand en los van het schadefeit, waar hij aan begint. Hij calculeert en aanvaardt dit risico

I22 In die woorden G.J.H. Van der Sangen, 'Omgekeerde doorbraak bij coöperaties en de (processuele) positie van haar leden', Stichting \& Vereniging, 200I, 2, par. 3.4.

I23 Zie artikel 7:66I en artikel 2:9 BW. Bij kapitaalvennootschappen waarin de bestuurder ook werknemer is, zouden die normen tot hetzelfde resultaat moeten leiden, vgl. HR 2 maart 2007, NJ 2007, m.nt. Westland v. Schieke en reeds Maeijer's NJ-noot bij Heino Krause, nr. 3 en Asser v. Maeijer v. Van Solinge \& Nieuwe Weme 2-II ${ }^{\star}$, nr. 44I.

I24 Doch zie op dit punt kritisch de NJ-annotatie van Maeijer onder Poot v. ABP, nr. I.

I25 Zie m.n. de annotatie van M.J.G.C. Raaijmakers onder Poot v. ABP, in: Vennootschapsrecht. Jurisprudentie en annotaties uit Ars Aequi 1952-1997 en uit de NJ en RvdW, Nijmegen: Ars Aequi Libri, p. 440 e.v.

I26 Van der Sangen 200I, par. 3.4.

I27 Tenzij een billijkheidsuitzondering zou worden aanvaard, zoals in HR 5 september I997, NJ I998, 437, m.nt. P. Van Schilfgaarde, Ontvanger v. Hamm. Van der Sangen 200I wijst op die (eventuele) escape.

I28 Aldus AG Hartkamp inzake Poot v. ABP, nr. 9 en vgl. HR I3 oktober 2000, NJ 2000, 699, m.nt. Ma, Heino Krause, r.o. 3.6.

I29 Dit punt is ontleend aan Van der Sangen 200I, die daarvoor waarschuwt in zijn bespreking van Heino Krause, met betrekking tot de leden van de (traditionele) coöperatie. 
en moet als dit zich verwezenlijkt, op de blaren zitten. Ik noemde dit in de inleiding het zogenoemde 'risicoperspectief': men weet met wie men precies in zee gaat en kent dus ook de risico's.

\subsubsection{De noodzaak van een specifieke zorgplicht}

Betekent dit perspectief dat men niet wordt beschermd? Dat zou, ook voor de economie, geen goede zaak zijn. Voor de vordering van aandeelhouders is echter wel nog plaats indien jegens de aandeelhouder zelf een specifieke zorgplicht is geschonden. Uit verschillende arresten blijkt echter dat van (de schending van) zo'n specifieke zorgplicht niet snel sprake is; de hoofdregel dat aandeelhouders geen eigen vordering toekomt, wordt niet snel opzij gezet. ${ }^{130}$ Enkel de wetenschap of voorzienbaarheid dat benadeling van de rechtspersoon ook nadeel voor de aandeelhouders zal meebrengen, is onvoldoende. Dit geldt niet alleen bij vorderingen tot schadevergoeding jegens kredietverstrekkers, maar ook bij andere vormen van benadeling van de vennootschap. Een veel aangehaald voorbeeld uit de rechtspraak is de onnodig trage schadeafwikkeling van de brandverzekeraar: ${ }^{13 \mathrm{I}}$ die mag wanprestatie opleveren jegens de vennootschap, maar is daarmee nog niet onrechtmatig jegens de aandeelhouders zelf.

Dit ontbreken van een zelfstandige grond voor aansprakelijkheid jegens de aandeelhouder met afgeleide schade geldt zelfs indien de schadeveroorzaker het opzet had om de vennootschap te benadelen. Zo is het onnodig en doelbewust veroorzaken van het faillissement van de vennootschap voor eigen gewin voor (de grondslag van) een individuele vordering van de aandeelhouder onvoldoende. Bijkomende omstandigheden zijn dan nodig, 'zoals het opzet om de aandeelhouder te benadelen'. ${ }^{132}$ Het mag duidelijk zijn dat daar niet gauw sprake van is; een bedrijfsbezetting die aanstuurt op faillissement bijvoorbeeld, waarna de aandelen niets meer waard zijn, lijkt nog niet te betekenen dat de vakbond met de bedrijfsbezetting ook het oogmerk heeft gehad om de aandeelhouder in persoon te benadelen. ${ }^{133}$

\subsubsection{Wel verhaalbare afgeleide schade van aandeelhouders}

Er zijn in de gepubliceerde rechtspraak van de laatste jaren (nog) weinig gevallen waarin de vordering van aandeelhouders voor afgeleide schade wordt toegewezen. De meest bekende uitzondering betreft het arrest Kip en Sloetjes v. Rabobank. ${ }^{134}$ Kip en Sloetjes waren enigaandeelhouders en tevens privé opgetreden als borg voor schulden van de vennootschap bij de bank. Maar naarmate die schulden verder opliepen,

I30 O.a. HR 29 november I996, NJ I997, I78, Cri Cri Geleen.

I3I HR 29 november I996, NJ I997, I78, Cri Cri Geleen.

I32 HR I6 februari 2007, NJ 2007, 256, m.nt. Ma, Tuin Beheer v. Houthoff Buruma.

I33 Vgl. de kwestie die ten grondslag lag aan HR I2 december I997, NJ I998, 348, m.nt. Ma, Ventaz Engineering v. FNV. Conclusie van Hartkamp voor Poot v. ABP, nr. I2; zie over de discussie of voorwaardelijk opzet voldoende is Maeijer in nr. 2 van zijn NJ-noot bij HR I2 december 1997, NJ I998, 348, m.nt. Ma, Ventaz Engineering v. FNV (ontkennend) en Du Perron, Bb I996, p. 53.

I34 HR 2 mei I997, NJ I997, 662, m.nt. Ma, Kip en Sloetjes v. Rabobank. 
heeft de bank op ongeoorloofde wijze druk op hen uitgeoefend om hun aandelen ver beneden de marktprijs te verkopen onder gelijktijdige opzegging van het krediet. De bank wist niet alleen dat het bedrijf hierdoor op faillissement afstevende, maar ook dat dit de aandeelhouders in persoon zou treffen. Door zijn positie als borg was Kip's privévermogen uiteindelijk afhankelijk van de mate waarin het vennootschapsvermogen ontoereikend was. Bovendien hadden Kip en Sloetjes schade als aandeelhouder: zowel het feit dat ze hun aandelen hadden verkocht als de te lage prijs die ze daarvoor hadden ontvangen waren het gevolg van het vennootschapsvermogen. Kip vorderde daarnaast nog vergoeding voor immateriële schade door het moeten opdoeken van een zelf opgebouwd bedrijf. Toch was de grondslag van deze vordering volgens de Hoge Raad 'van geheel andere aard' dan in de zaak die ten grondslag lag aan het Poot $v$. ABP-arrest en in beginsel voor vergoeding vatbaar. ${ }^{135}$

Een kleine variant hierop biedt het arrest Kessock v. SFT Bank. ${ }^{13^{6}}$ Dit betreft de vordering van grootaandeelhouders die eveneens de bank aansprakelijk stellen voor het kredietbeleid nadat de vennootschap in financiële moeilijkheden is geraakt. De bank had met één van hen in privé een afspraak gemaakt over de kredietvoorwaarden, namelijk om na de storting van een bepaald bedrag door die aandeelhouder in privé nog een bepaalde som op het debetsaldo in mindering te brengen. Daar kwam nog bij dat men zich, vergelijkbaar met Kip en Sloetjes, persoonlijk hoofdelijk aansprakelijk moest stellen voor het debetsaldo van de vennootschap boven een bepaald bedrag. De bank kwam de afspraak niet na, waardoor de vennootschap niet meer going concern kon worden verkocht. Hierdoor moesten de grootaandeelhouders hun aandelen voor een lager bedrag verkopen dan bij tijdige storting vermoedelijk nodig zou zijn geweest. In de hier gestelde feiten lag volgens de Hoge Raad de mogelijkheid besloten dat er sprake is van een wanprestatie of onzorgvuldigheid jegens de aandeelhouders zelf. ${ }^{137}$

\subsubsection{Verband tussen deze zaken}

In beide zaken is de afgeleide schade het gevolg van persoonlijke betrekkingen die de aandeelhouder ten behoeve van de vennootschap is aangegaan en zijn de aandelen bovendien verkocht tegen een lagere prijs dan die naar verwachting zonder de normschending zou zijn ontvangen. Verdedigd is dat de schade in dat geval in feite geen 'afgeleid' karakter (meer) heeft: bij de koopprijs had immers rekening moeten worden gehouden met de vordering tot schadevergoeding van de vennootschap zelf. ${ }^{13^{8}}$ Daar zou dan wellicht ook de verklaring voor de uitbreiding van de verhaalsmogelijkheden kunnen liggen: deze schade kan niet (meer) worden goedgemaakt door een vordering tot schadevergoeding van de vennootschap of door de curator.

I35 Zie Kip en Sloetjes v. Rabobank, r.o. 3.6.

I36 R.o. 3.4; onder verwijzing naar de arresten Poot v. ABP en Tuin Beheer v. Houthoff Buruma.

I37 HR 2 november 2007, NJ 2008, 5 m.nt. Ma, Kessock v. SFT Bank.

I38 Kroeze 2004; Van Wijk 2008. 


\subsubsection{De sleutel ligt niet zozeer bij het definitief worden van de schade}

Maar inmiddels is er in de literatuur veelvuldig op gewezen dat de Hoge Raad in Kessock v. SFT Bank nu juist nadrukkelijk spreekt van 'afgeleide schade'. ${ }^{139}$ Uit eerdere uitspraken blijkt bijvoorbeeld ook al dat het ontbreken van de mogelijkheid voor de vennootschap om een vordering in te stellen geen grond oplevert voor uitbreiding van de aansprakelijkheid naar aandeelhouders met afgeleide schade. Zo lijkt te volgen uit het Heino Krause-arrest dat het gegeven dat de rechtspersoon door fusie niet meer bestaat (en dus als zodanig geen vordering meer kan instellen) nog niet meebrengt dat de schade van de individuele leden definitief is geworden. ${ }^{140}$ Ook als er geen vordering kan worden ingesteld, levert dat geen grond op voor een uitbreiding van aansprakelijkheid..$^{\mathrm{I} 4 \mathrm{I}}$ Dit punt kwam naar voren in het Chipshol-arrest: ${ }^{\mathrm{I} 42}$ de omstandigheid dat de vennootschap 'buiten staat is of zichzelf buiten staat heeft gesteld' om een vordering voor haar schade in te stellen, betekent nog niet dat de aandeelhouders hun 'afgeleide schade' kunnen verhalen. De accountant had een goedkeurende verklaring voor de jaarrekening afgegeven op de voorwaarde dat de vennootschap van vorderingen tegen zijn maatschap zou afzien. Dat 'ongeoorloofde pressiemiddel' was jegens de aandeelhouder niet onrechtmatig.

Ook faillissement van de vennootschap biedt zelden ruimte voor een eigen vordering van de aandeelhouders. In het arrest Van de Mosselaar Vastgoed v. X had de eiser/ aandeelhoudster getracht om zich de vordering van de vennootschap te laten cederen, maar de curator had niet tijdig mededeling gedaan aan de schuldenaar. Dat de cessie daardoor niet rechtsgeldig was geschied, maakte überhaupt het 'afgeleid' (en dus niet verhaalbaar) zijn van haar schade niet anders. ${ }^{\mathrm{I} 33}$ Ook als de vordering van de vennootschap wel wordt ingesteld, maar niet succesvol is, geeft dat de aandeelhouders geen argument voor een eigen individuele vordering. In de hiervoor genoemde kwestie Kessock $v$. SFT Bank had de vennootschap in een eerdere procedure een onrechtmatige daadvordering ingesteld tegen de bank, die toen was afgewezen. De vennootschap berustte in dat oordeel. De schade van de aandeelhouders, die bestond uit een (van de vermogensvermindering afgeleide) waardevermindering van hun aandelen, was daarmee feitelijk 'definitief' geworden. Maar die omstandigheid brengt dus op zichzelf niet mee dat de aandeelhouders alsnog aan de benadeling van de vennootschap een eigen vordering tot schadevergoeding kunnen ontlenen. ${ }^{\text {I4 }}$

Volgens mij kan hieruit worden geconcludeerd dat het gegeven dat de schade in werkelijkheid niet door een vordering van de vennootschap kan worden hersteld nog geen grond oplevert voor een zelfstandige vordering van de aandeelhouder. Het lijkt

I39 HR 2 november 2007, NJ 2008, 5 m.nt. Ma, Kessock v. SFT Bank.

I40 HR I3 oktober 2000, NJ 2000, 699, m.nt. Ma, Heino Krause.

I4I Heino Krause, r.o. 3.6.

I42 HR I5 juni 200I, NJ 200I, 573, m.nt. Ma, Chipshol c.s. v. X en Y.

I43 HR I4 juli 2000, NJ 200I, 685, m.nt. S.C.J.J. Kortmann, Van de Mosselaar Vastgoed v. X.

I44 HR 2 november 2007, NJ 2008, 5, m.nt. Ma, Kessock v. SFT Bank. 
dan ook onwaarschijnlijk dat het verkocht zijn van de aandelen, waarvan sprake was in de zaak Kip en Sloetjes en Kessock dat wel is.

\subsubsection{Een verschuiving van risicoperspectief naar een zeker 'hulpperspectief'?}

De sleutel voor de verklaring van de uitbreiding van aansprakelijkheid naar afgeleide schade in deze beide zaken ligt veeleer bij de rechtsbetrekking die de aandeelhouders in kwestie hadden ten aanzien van het vermogen van de vennootschap: ze waren als geldschieter of borg waren opgetreden en daarmee rechtstreeks in contact getreden met de bank: ze waren dus veeleer 'primair benadeelde' en geen derde meer. De Hoge Raad formuleert dit (uiteraard) anders en noemt het door de aandeelhouder als contractspartij van de vennootschap optreden, uit privévermogen aflossen van vennootschapsschulden en het zich hoofdelijk aansprakelijk stellen voor eventuele kredietoverschrijdingen. Betekent dit dat de verhaalsmogelijkheden voor aandeelhouders met afgeleide schade in het geheel niet aan bijzondere beperkingen onderhevig zijn indien die in feite mede verband houdt, of zou kunnen houden, met contractuele betrekkingen die ze in persoon met de vennootschap onderhielden dan indien die betrekking heeft op aandelen? ${ }^{\text {I45 }}$

Dit punt - transformatie van aandeelhouder naar schuldeiser - was recenter aan de orde in de zaak Tuin Beheer v. Houthoff Buruma: door aantasting van het vennootschapsvermogen bleef een aanzienlijk deel van de rekening-courantvordering op de vennootschap onvoldaan. De aandeelhouder vorderde tevens in zijn hoedanigheid van schuldeiser schadevergoeding voor die onvoldaan gebleven schuld. ${ }^{{ }^{146}}$ De schade bestond dus niet uit een vermindering van de waarde van de aandelen, maar uit een vermindering van de waarde van de vordering. Op basis van dit arrest kan verschil worden gemaakt tussen de waardevermindering van aandelen die het gevolg is van aantasting van het vennootschapsvermogen (afgeleide schade die niet wordt vergoed) en de waardevermindering van een onvoldaan gebleven vordering uit de rekening-courant (afgeleide schade die eventueel wel voor vergoeding in aanmerking komt).

In het laatste geldt dan voor schuldeisers het criterium van het arrest Vleesmeesters/ Alog: ${ }^{147}$ de belangen van de schuldeiser moeten 'zo nauw betrokken zijn' bij (wél) naleving van de norm door de schadeveroorzaker (die hier bestond uit de deugdelijke nakoming van een contractuele verplichting), dat de schadeveroorzaker zijn gedrag mede op die belangen had moeten afstemmen. In de literatuur wordt er op gewezen dat het onrechtmatigheidregime voor schuldeisers helemaal niet noodzakelijk minder terughoudend is. ${ }^{148}$ Van Wijk wijst op de betrekkelijke onbepaaldheid en de verschillende context van het criterium en de norm van het arrest Vleesmeesters $v$. Alog, nu dat strikt genomen is geformuleerd voor een contractuele context en ook met name is toegepast in gevallen waarin sprake is van sterk samenhangende contrac-

I45 Vgl. nog afwijzend (bij het Hof), HR 6 december I957, NJ I958, 40, Goekoop v. Terwogt.

I46 HR I6 februari 2007, NJ 2007, 256, m.nt. Ma, Tuin Beheer v. Houthoff Buruma.

I47 HR 24 september 2004, NJ 2008, 587, m.nt. C.E. du Perron, Vleesmeesters Versman v. Alog.

I48 Zie hierna, par. $3 \cdot 5$. 
tuele verhoudingen. Volgens hem had de Hoge Raad beter kunnen verwijzen naar de norm voor 'klassieke' externe bestuurdersaansprakelijkheid, dat de aangesproken bestuurder een 'voldoende ernstig verwijt' moet treffen. ${ }^{\text {I49 }}$

\subsubsection{Tussenbeschouwing}

We zien hier enige parallellen met de visie op de derde als 'hulpverstrekker', die hiervoor werd beschreven voor schadeverzekeraars, professionele hulpdiensten, zorgverleners en dergelijke. Toegegeven, deze zaken zijn niet vergelijkbaar met de onderhavige uitbreiding van de aansprakelijkheid naar afgeleide schade ingevolge Kip en Sloetjes $v$. Rabobank en Kessock v. SFT Bank. ${ }^{150}$ Maar iets van een hulpelement speelt ook hier een rol. Cruciaal was in beide arresten dat de aandeelhouders (ook) schade hadden in de hoedanigheid van borg of kredietverstrekker, die het gevolg was van de benadeling van de vennootschap. Juist in die hoedanigheid zijn ze financieel voor de vennootschap persoonlijke betrekkingen aangegaan om uit hun privévermogen vennootschapsschulden af te lossen.

Maar waarom geldt een bijzonder criterium voor de (aandeelhouder-)schuldeiser die een derdenschadevergoeding instelt voor het waardeverlies op rekening courant of geldvorderingen? Voor het antwoord op die vraag is het goed om eerst de algemene verhaalsmogelijkheden van schuldeisers nader te bezien. In de eindconclusie zal ik op deze vraag terugkomen.

\subsection{Schade van schuldeisers door aantasting van het vermogen van de onderneming}

\subsubsection{Overzicht}

Hierna zal worden ingegaan op de verhaalsmogelijkheden van schuldeisers voor schade die verband houdt met een vermindering van het vermogen van een kapitaalvennootschap. Daarbij wordt eerst het criterium van Vleesmeesters $v$. Alog nader uiteengezet (paragraaf 3.5.2). Daarna zullen enkele bijzondere gevallen van beroepsaansprakelijkheid, met name van banken, worden besproken (paragraaf 3.5.3) en wordt ingegaan op gevallen van bestuurdersaansprakelijkheid (paragraaf 3.5.4). Ten slotte komt nog kort een totaal andere kwestie aan bod, om te laten zien hoe moeilijk hanteerbaar het 'afgeleide schade'-criterium wordt als dit buiten het standaardgeval van verminderde verhaalsmogelijkheden zou worden toegepast. Het gaat in die kwestie om het aan de onderneming gelieerde vermogensbelang van werknemers (paragraaf 3.5.5). ${ }^{\text {I51 }}$

I49 Van Wijk 2008.

I50 Par. 3.4.6.

I5I Dit is maar een greep van de derden waar aan kan worden gedacht, bij Kroeze worden onder meer nog certificaathouders genoemd, houders van een pandrecht of recht van vruchtgebruik op aandelen en obligatiehouders. 


\subsubsection{Het criterium van Vleesmeesters v. Alog}

Van 'afgeleide schade' van schuldeisers wordt gesproken indien hun verhaalsmogelijkheden worden aangetast doordat het ondernemingsvermogen is verminderd, bijvoorbeeld door een verkeerd besluit tot het aangaan van een nieuwe verbintenis met anderen of tot winstuitkering. Hiervoor merkte ik op dat als individuele schuldeisers verhaal zoeken voor die schade, als uitgangspunt geldt dat het plegen van wanprestatie of van een onrechtmatige daad jegens een onderneming nog niet een onrechtmatige daad jegens hen zelf impliceert. ${ }^{152}$ Voor de schuldeiser zou het criterium gelden van het arrest Vleesmeesters $v$. Alog, dat erop neerkomt dat zijn belangen zo nauw betrokken zijn bij de behoorlijke naleving van verplichtingen dat hij schade of ander nadeel kan lijden als men tekortschiet. ${ }^{153}$ Indien dat het geval is, dan kan dat meebrengen dat de schadeveroorzaker hem had moeten ontzien of zijn gedrag mede door die derdebelangen had moeten bepalen.

Bij de beoordeling of aan het criterium van Vleesmeesters $v$. Alog is voldaan, dient de rechter alle omstandigheden van het geval te betrekken. De Hoge Raad doet een greep ('zoals'): de hoedanigheid van alle betrokken partijen, de aard en strekking van de overeenkomst, de wijze waarop de belangen van de derde daarbij zijn betrokken, de vraag of deze betrokkenheid voor de contractant kenbaar was, de vraag of de derde erop mocht vertrouwen dat zijn belangen zouden worden ontzien, de vraag in hoeverre het voor de contractant bezwaarlijk was met de belangen van de derde rekening te houden, de aard en omvang van het nadeel dat voor de derde dreigt en de vraag of van hem kon worden gevergd dat hij zich daartegen had ingedekt, alsmede de redelijkheid van een eventueel aan de derde aangeboden schadeloosstelling. De term 'derde' lijkt hier overigens te worden verstaan als 'buitenstaander bij de overeenkomst' en dus niet als degene met 'uit andere schade voortvloeiende schade'. Deze term heeft, om met Spier te spreken, ${ }^{154}$ geen vastomlijnde juridische betekenis. Maar voor de onderhavige context, waarin er in ieder geval sprake is van derdenschade zoals gedefinieerd in de inleiding, kan dit in het midden blijven.

\subsubsection{Beroepsaansprakelijkheid voor derdenschade van schuldeisers}

Bij de aansprakelijkheid jegens schuldeisers wegens benadeling van de debiteur/ onderneming valt vooral te denken aan het optreden van banken. De Hoge Raad heeft allang in bredere zin aanvaard dat op banken onder bijzondere omstandigheden zorgplichten kunnen rusten jegens anderen dan hun cliënten. ${ }^{155}$ Specifiek de verhaalsmogelijkheden van individuele schuldeisers waren aan de orde in het Erba I-arrest. Deze zaak betrof de vordering tot schadevergoeding van de leverancier van textielgoederen jegens de bank van haar contractuele wederpartij. De bank zou

I52 We zagen dat eerst ook voor aandeelhouders, zie par. 3.4.3.

I53 HR 24 september 2004, NJ 2008, 587, Vleesmeesters Versman v. Alog, m.nt. C.E. du Perron.

I54 In nr. 6.3 van zijn Conclusie voor HR 7 mei 20I0, LJN BL627I, Ontvangsttheorie.

I55 Zie bijvoorbeeld HR g januari I998, NJ I999, 285, m.nt. WMK, Mees Pierson v. Ten Bos en het hierna in de hoofdtekst genoemde arrest HR 23 december 2005, NJ 2006, 289, m.nt. MRM, Fortis v. Stichting Volendam. 
onrechtmatig jegens haar hebben gehandeld door een omvangrijk krediet wegens de ongunstige financiële omstandigheden van de onderneming op te zeggen, maar vervolgens een hernieuwd krediet van een bijna zo groot bedrag te verlenen maar dan met de zekerheidsstelling van alle bestaande en toekomstige activa van die onderneming (en de achterstelling van alle vorderingen bij die van de bank). Hiermee had de bank voor zichzelf alle risico uitgesloten, maar gefaciliteerd dat er voor derden de schijn was van zelfstandigheid en kredietwaardigheid. De aan de onderneming geleverde goederen gingen, zonder dat die de koopprijs had voldaan, in eigendom over op de bank, die weigerde om ze terug te geven. In feite betaalde die onderneming daardoor dus, met andere nieuwe schuldeisers, het krediet af dat de onderneming bij de bank had uitstaan. De bank stelde daar tegenover dat de schade van de schuldeiser het gevolg was van haar eigen falende debiteurenbeleid. Zo had zij (onder andere) de termijn laten verstrijken om het reclamerecht in te roepen of om de desbetreffende koopovereenkomsten te (laten) ontbinden.

Maar de schuldeiser kreeg bij de Hoge Raad gelijk. ${ }^{156}$ Benadrukt werd met zoveel woorden de voorzienbaarheid van derdenschade voor de bank: de bank wist of had kunnen voorzien dat dit kredietbeleid (ook) nieuwe schuldeisers zoals de eiser hun verhaalsmogelijkheden zou ontnemen en handelde daarom onrechtmatig jegens haar, als belanghebbende derde. Dit zou anders zijn geweest als de bank de onderneming tevoren in de gelegenheid had gesteld om de schuldeiser/leverancier te betalen of de goederen terug te geven. Wel oordeelt de Hoge Raad dat van de leverancier zelf mag worden verlangd dat die niet stil blijft zitten wanneer de betaling niet vlot verloopt en dat die zijn risico zeker niet vergroot door het doen van nieuwe leveranties.

In het Fortis-arrest is zo'n bijzondere zorgplicht van de bank ook aangenomen ten behoeve van beleggers die zwaar gedupeerd waren geraakt door beleggingsactiviteiten van een van de rekeninghouders. ${ }^{157}$ De bank had eerst na het openen van de rekening bekendheid verkregen omtrent de omvang en het doel van de gestorte bedragen. Vanaf dat moment had de bank de activiteiten van de rekeninghouder niet op zijn beloop mogen laten (en dus faciliteren) zonder zelf te onderzoeken of er werd gehandeld overeenkomstig de Wet toezicht effectenverkeer (Wte). Door dit niet te doen, heeft de bank de beleggers blootgesteld aan de risico's van malafide praktijken die de Wte nu juist beoogt uit te sluiten en daardoor in beginsel ook zelf onrechtmatig jegens hun gehandeld, als belanghebbende derden. ${ }^{15^{8}}$ Hier wordt de term derden wederom anders verstaan dan zoals ik hem in de inleiding heb gedefinieerd, namelijk in de zin dat de beleggers geen eigen cliënten van de bank waren. Kortom, dat ze geen contractuele relatie met de bank zelf onderhielden, en dus in die zin 'derde' waren. ${ }^{159}$ Net als in het Erba-arrest had de bank de plicht (volgens de Hoge Raad in het Fortis-arrest: de 'maatschappelijke' plicht) om de vermogensbelangen te bewaken van bepaalde contractuele relaties van haar rekeninghouders.

I56 HR 28 juni I957, NJ I957, 5I4, m.nt. LEHR, Manifattura Tessile Erba v. Amsterdamsche Bank.

I57 HR 23 december I995, NJ 2006, 289, Fortis Bank v. Stichting Volendam, m.nt. MRM.

I58 R.o. 6.3.3 en 6.3.4. Zie hierover ook de NJ-noot van Mok onder dit arrest.

I59 Vgl. HR 23 mei I997, NJ I998, I92, Rabo v. Everaars, m.nt. C.J. van Zeben en HR 9 januari I998, NJ I999, 285, Mees Pierson v. Ten Bos, m.nt. W.M. Kleyn. 
Het terrein van beroepsaansprakelijkheid biedt vele andere voorbeelden van derdenschade in deze zin. Een uit het notariaat bekend voorbeeld over de benadeling van schuldeisers zagen we in de THB-arresten. De zaak is bekend: door de Tilburgsche Hypotheekbank werden hypothecaire geldleningen afgesloten die vaak de waarde van het ondergezette onroerend goed aanzienlijk te boven gingen. Daardoor beschikte de bank over onvoldoende verhaalsmogelijkheden toen de verplichtingen uit die geldleningen door de schuldenaren niet werden nagekomen. De totale benadeling van de THB door deze overfinanciering is geschat op ruim 78,7 miljoen gulden. Na de faillietverklaring van de THB hebben de curatoren van de THB namens de gezamenlijke schuldeisers tegen drie notarissen een schadevordering ingesteld van tientallen miljoenen guldens, hetgeen tot een drietal arresten van de Hoge Raad heeft geleid. ${ }^{160}$ De bijzondere positie van de notaris, zoals geregeld door de Wet op het notarisambt, brengt mee dat hij bij zijn ambtsbediening ook een zorgplicht kan hebben jegens mogelijk betrokken derden. Daarvan kan sprake zijn in die gevallen, waarin voor de notaris voorzienbaar is dat bedoeld tekortschieten schade bij derden teweegbrengt. Voor het onderhavige geval geldt een terughoudende maatstaf: voorzienbaar moest zijn een 'ernstig gevaar voor insolventie' van de THB. Die brengt tot uitdrukking dat slechts onder bijzondere omstandigheden sprake is van een zorgplicht van de notaris jegens derden. ${ }^{\mathrm{I}}{ }_{\mathrm{r}}$ Dit had overigens niet alleen ermee te maken dat het om de zorgplicht ging jegens de schuldeisers, maar ook dat de handelende partijen (THB en een beperkte groep onroerend goedhandelaren) deskundig waren.

Interessant is hier volgens mij nog een ander punt. Aandacht krijgt namelijk nadrukkelijk nog de verhouding van de vordering voor de derdenschade van de schuldeisers en die voor de schade van de primair benadeelde (de THB zelf). De Hoge Raad beslist dat de eerstbedoelde vordering niet hoeft te worden achtergesteld bij de tweede, in de zin dat de vergoeding van de derdenschade slechts zou kunnen worden toegekend voor zover zij het bedrag van de door THB zelf geleden schade overtreft.

\subsubsection{Bestuurdersaansprakelijkheid jegens schuldeisers met afgeleide schade}

Hier dient nog te worden stilgestaan bij gevallen waarin de vordering voor de afgeleide schade van de schuldeiser tegen bestuurders (of commissarissen) ${ }^{162}$ van de vennootschap is gericht. Zoals bekend gelden er, om het persoonlijk risico van bestuurders beheersbaar te houden (denk aan vorderingen van Ceteco-magnitude), ${ }^{163}$ bijzondere criteria die erop neerkomen dat ernstig persoonlijk falen is vereist. Daarbij moeten we differentiëren al naar gelang er sprake is van faillissement.

I6o HR 23 december 1994 en HR I5 september I995, NJ I996, 627-629, m.nt. WMK, Tilburgsche Hypotheekbank.

I6I HR 23 december I994, NJ I996, 627 (m.nt. WMK onder NJ I996, 629), Tilburgsche Hypotheekbank.

I62 Zie artikel 6:I62 BW en artikel 2:I5o/26o BW (en overigens artikel 2:I49/259 BW juncto artikel 2:9 BW en artikel 2:138/248 BW voor interne aansprakelijkheid). De commissaris als aangesprokene laat ik nu echter verder buiten beschouwing.

I63 Rb. Utrecht I2 december 2007, LJN BB9709, Curatoren/bestuurders en commissarissen Ceteco c.s. 
Uitgangspunt is dat de curator in faillissement collectief schadevergoeding vordert ten behoeve van de gezamenlijke schuldeisers. ${ }^{164}$ De curator vordert dan schadevergoeding voor het totaal van de schulden voor zover die niet door vereffening van de overige baten kunnen worden voldaan. Nodig is dat het faillissement 'in belangrijke mate' is veroorzaakt door 'kennelijk onbehoorlijk bestuur', in de zin dat de bestuurders wisten of hadden moeten weten dat door hun gedrag uiteindelijk de schuldeisers zouden worden benadeeld. De wet geeft daarvoor een aantal bewijsvermoedens die, zoals bekend, in de praktijk als heilzaam worden ervaren. ${ }^{165}$ Indien sprake is van 'ernstig verwijtbaar' onbehoorlijk bestuur, kan de curator ook nog schade vorderen die daardoor aan (het vermogen van) de vennootschap is toegebracht. In beide gevallen kan de te ontvangen schadevergoeding er indirect toe leiden dat de schuldeisers alsnog kunnen worden voldaan, maar alleen bij een ernstig verwijt profiteren indirect ook de aandeelhouders. ${ }^{166}$

Maar eenvoudiger dan ik hiervoor voor de aandeelhouders heb laten zien, kunnen schuldeisers ook individueel een vordering tot schadevergoeding instellen tegen een bestuurder voor hetzelfde feitencomplex. Dan gelden er ook wel beperkingen, die zeker ook ingrijpend zijn, maar die hebben toch een wat formeler karakter: de individuele schuldeisers profiteren niet van de regeling voor kennelijk onbehoorlijk bestuur (art. 2:138/248 BW), dat wil zeggen van de belangrijke bewijsvermoedens die deze regeling biedt, en bovendien moeten ze zich dan, om fricties te vermijden, laten welgevallen dat eerst over de vordering van de curator wordt beslist. ${ }^{167}$ Bovendien kan de schadeveroorzaker, omgekeerd, bij de collectieve bevoegdheid van de curator in beginsel aan hem niet de verweren tegenwerpen die hij heeft tegen specifieke schuldeisers. ${ }^{168}$

Om het wat concreter te maken: in de kwestie Lünderstadt v. De Kok bestond de schade van de desbetreffende schuldeiser uit het niet kunnen executeren van een veroordelend vonnis tot een door de vennootschap aan hem verschuldigde geldsom. Zijn verhaalsmogelijkheden waren, zo stelde hij, verminderd tengevolge van schade die door de aangesproken bestuurders aan de vennootschap zou zijn toegebracht. Deze schade kon door de curator collectief worden afgewikkeld; sterker nog, de curator had ook daadwerkelijk mede in zijn belang collectief schadevergoeding

I64 Timmerman I998, nr. 8-9.

I65 Zie artikel 2:I38/248 lid 2 BW en B.F. Assink, Rechterlijke toetsing van bestuurlijk gedrag, Deventer: Kluwer, 2007, p. 628.

I66 Vgl. het voorbeeld van M.L. Lennarts, 'Titel 8 van het Voorontwerp Insolventiewet: bestuurdersaansprakelijkheid ingeval van faillissement', Ondernemingsrecht 2008, afl. 13, p. 460-467, par. 3.2.

I67 HR 2I december 200I, NJ 2005, 95, Lünderstadt v. De Kok c.s. en HR 2I december 200I, NJ 2005, 95, Sobi v. Hurks c.S., m.nt. SCJJK. Zie kritisch F.M.J. Verstijlen, 'De onrechtmatige-daadsvordering wegens de benadeling van schuldeisers binnen faillissement: één voor allen en ieder voor zich', WPNR 2002/6502, p. 617-626.

I68 In het Voorontwerp Insolventiewet wordt wel een wettelijke grondslag voorgesteld voor analogische toepassing van artikel 6:Ior BW bij de berekening van het tekort en de verdeling van de opbrengst daarmee rekening te houden. Er wordt gewezen op schuldeisers die op onredelijke wijze hun medewerking aan een gerechtelijk akkoord hebben geweigerd of, als het om kredietverschaffers gaat, het krediet abrupt hebben beëindigd (S.C.J.J. Kortmann \& N.E.D. Faber (red.), Geschiedenis van de Faillissementswet. Deel IV: Voorontwerp insolventiewet, Serie Recht en Onderneming 2-IV, Deventer: Kluwer, 2007, toelichting bij artikel 8.2 lid 7). 
gevorderd, maar de schuldeiser was (kennelijk) niet tevreden met het resultaat. De Hoge Raad stond deze cumulatie van vorderingen zoals gezegd toe, zij het met de twee al genoemde formele restricties. Wellicht gelden hier gedeeltelijk dezelfde bezwaren als die bij de aandeelhouders werden genoemd (paragraaf 3.4.4). Maar in de desbetreffende arresten ging het over een (mogelijk) belangrijk ander bezwaar, namelijk de mogelijk gespannen verhouding met de paritas creditorum, maar die achtte de Hoge Raad daar niet in het geding. ${ }^{169}$

Er gelden dus toch wel wat beperkingen voor het honoreren van individuele vorderingen van schuldeisers wier verhaalsmogelijkheden slechts indirect, via het vennootschapsvermogen, zijn aangetast. ${ }^{170}$ Anders is dat voor zover op onrechtmatige wijze aan de schuldeiser schade is toegebracht, die niet is afgeleid van schade die aan het vennootschapsvermogen is toegebracht. ${ }^{171}$ Twee typen gevallen kunnen hier tot bestuurdersaansprakelijkheid leiden. ${ }^{172}$

In het eerste type individuele vordering van schuldeisers dat kan slagen, is de bestuurder namens de vennootschap verplichtingen aangegaan, terwijl hij wist of behoorde te begrijpen dat de vennootschap die niet binnen een 'redelijke termijn' zou kunnen nakomen en daarvoor dan ook nog eens geen verhaal zou bieden, de Beklamel-norm. ${ }^{\mathrm{I} 3}$ Voor vorderingen van 'nieuwe' schuldeisers betoogt Van Eeghen dat ze deels zien op hetzelfde verlies als waardoor alle schuldeisers benadeeld zullen worden. ${ }^{174}$ Dat is een ingewikkelde problematiek, waar ik me hier niet aan wil en wellicht ook niet hoeft te branden; zij ziet veeleer op de samenloop van vorderingen, ${ }^{175}$ die niet helemaal een-op-een gaat met de vraag of sprake is van afgeleide schade. Ik volsta met de stelling dat 'afgeleide' schade feitelijk in zoverre niet aan de orde is, dat op de onderneming contractueel weliswaar de verplichting rust tot betaling (waardoor het passief is toegenomen), ${ }^{176}$ maar haar vermogen ontoereikend is en dus feitelijk veelal niet kleiner zal worden.

I69 Zie hierover AG Huydecoper, in zijn conclusie voor Lünderstadt v. De Kok c.s., nrs. 2 I-22 en Kortmann in zijn noot met betrekking tot beide arresten, onder NJ 2005, 96, Sobi v. Hurks c.s., nr. 4.

I70 Rb. 's-Hertogenbosch 2 augustus I996, JOR I996, IIo, m.nt. NED Faber, Dortangs c.s. v. Coppelmans.

I7I Faber in de annotatie onder JOR I996, IIo.

I72 Zie het aanvankelijke HR I8 februari 2000, NJ 2000, 295, New Holland Belgium v. Oosterhof, m.nt. Ma en nr. I van Maeijer's instructieve noot en daarop in duidelijke bewoordingen HR 8 december 2006, NJ 2006, 659, Ontvanger v. Roelofsen. 'Voldoende' impliceert terughoudendheid, Asser/ Maeijer/Van Solinge \& Nieuwe Weme 2-II^, nr. 448.

I73 HR 6 oktober I989, NJ I990, 286, m.nt. Ma, Beklamel en zie HR I5 januari I993, NJ I993, 301, m.nt. Ma en HR I4 november I997, NJ I998, 270, m.nt. Ma, Henkel. De Beklamel-norm heeft vooral betekenis bij faillissement en moet volgens het Voorontwerp Insolventiewet van de commissie Kortmann in het faillissementsrecht worden neergelegd, naast overheveling van artikel 2:138/248 BW. Kritisch Lennarts 2008.

I74 L.J. Van Eeghen, 'De aansprakelijkheid van bestuurders na feitelijke insolventie', TvI 2002, p. $197-205$, nr. 8.

175 De curator is niet bevoegd voor schuldeisers vergoeding voor onbetaald gebleven nieuwe verplichtingen te vorderen en als boedelschuld uit te keren (HR I6 september 2005, NJ 2006, 3II, m.nt. PvS, De Bont v. Bannenberg q.q.). Zie Van Eeghen.

I76 Waar eventueel toegenomen actief tegenover staat, dat dan verdisconteerd moet worden, hierover Van Eeghen 2002, nr. 5. 
Het tweede type gevallen waarin aansprakelijkheid jegens individuele schuldeisers pleegt te worden aangenomen, zijn gevallen waarin de bestuurder feitelijk heeft verhinderd dat de vennootschap haar verplichting jegens de schuldeiser nakwam. Van zo'n persoonlijk ernstig verwijt 'kan' volgens de Hoge Raad onder meer sprake zijn als de bestuurder wist dat of moest weten dat de door hem bewerkstelligde of toegelaten handelwijze van de vennootschap tot gevolg zou hebben dat die haar schulden niet zou kunnen nakomen. Het arrest Waning $v$. Van der Vliet biedt een voorbeeld van betalingsonmacht van de vennootschap die het gevolg is van betalingsonwil van de bestuurder. ${ }^{177}$ Ook hier lijkt van afgeleide schade in de meest feitelijke zin niet noodzakelijk sprake; zeker niet als de bestuurder het verwijt krijgt dat hij er niet voor heeft gezorgd dat de schuldeiser werd voldaan uit beschikbare kredietfaciliteiten. ${ }^{17} 8$

\subsubsection{Derdenschade die geen 'afgeleide schade' is}

Buiten de hiervoor besproken gevallen wordt het begrip 'afgeleide schade' bij de vraag naar de verhaalsmogelijkheden van derden bij aantasting van het vennootschapsvermogen eigenlijk niet gehanteerd. Dat neemt niet weg dat er ook dan natuurlijk best ook sprake kan zijn van derdenschade, zij het in een ander opzicht dan bij de besproken gevallen van aandeelhouders en de algemene schuldeisers die in hun verhaalsmogelijkheden worden aangetast. Denk aan werknemers die in rechtspositioneel of ander opzicht schade ondervinden van benadeling van een onderneming. Het grote verschil is hier dat hun schade dan niet parallel loopt met de vermindering van het vennootschapsvermogen en het, nu het ook om heel andere belangen gaat dan de verliezen van aandeelhouders en schuldeisers, geen gevallen zijn van 'afgeleide schade'.

Het is niet mijn bedoeling die gevallen in dit preadvies allemaal de revue te laten passeren. Maar illustratief voor deze derdenschade die geen 'afgeleide schade' is, is wellicht de kwestie De Boek v. Van Gorp, ${ }^{179}$ waarin een drukkerij amper een maand na een mislukte poging tot ontslag van haar enig werknemer, op eigen aangifte failliet is verklaard. De werknemer is daarop alsnog door de curator ontslagen en één week na de faillietverklaring is door de voormalig bestuurder, tevens indirect enig aandeelhouder, een nieuwe drukkerij gestart, ditmaal met beslotenvennootschapsconstructie. In het onderhavige geding stelt de ontslagen werknemer met succes dat de faillissementsaanvraag jegens hem onrechtmatig is geweest. De Hoge Raad verstaat het hof zo, dat het 'kennelijk' heeft geoordeeld dat de bevoegdheid daartoe voor een ander doel is gebruikt dan waarvoor die is verleend: met het vooropgezette doel om te bewerkstelligen dat de onderneming zonder de werknemer en zonder diens arbeidsrechtelijke bescherming feitelijk kon worden voortgezet. Dat oordeel laat de Hoge Raad in stand.

I77 HR 3 april I992, NJ I992, 4II, Van Waning v. Van der Vliet.

I78 Hier kan overigens in het midden of en wanneer nu precies zo'n nalatigheid een (voldoende) ernstig verwijt kan opleveren, doch zie daarover Asser/Maeijer/Van Solinge \& Nieuwe Weme 2-II*, nr. 469 (met verwijzingen).

I79 HR 28 mei 2004, NJ 2006, 4, De Boek v. Van Gorp. 


\section{Conclusie}

\section{I Terug naar het spanningsveld en de twee polen}

Ik zal tot een afronding komen. Het thema derdenschade laat een spanningsveld zien: er is de aanname dat derdenschade moet worden vergoed, maar ook juist dat zij moet worden beperkt. Hoewel de hiervoor besproken vergoedingsregels vaak in het licht worden geplaatst van de beperkingen van verhaalsmogelijkheden, heb ik vooral belicht dat daarmee dan wel is erkend en mogelijk gemaakt dat derdenschade wordt vergoed. . $^{180}$

Voor het spanningsveld van discussies over derdenschade gelden er twee polen. De ene pool is ingegeven vanuit een visie op de derde als de 'hulpverstrekker' van de primair benadeelde: het hulpperspectief. De andere pool is juist ingegeven vanuit de visie op de derden als degene die 'beter' hadden moeten weten: het risicoperspectief. Dit laatste betreft derden die, voorafgaand aan het schadevoorval, reeds toen calculeerbare risico's zijn aangegaan. ${ }^{18 \mathrm{r}}$ De besproken vergoedingsregimes plaatste ik steeds in het licht van deze perspectieven. Ik zal hierna de balans opmaken van deze analyse.

\subsection{Algemene conclusies}

Hoewel we ervoor moeten waken te algemene conclusies te zoeken, heeft het voorgaande wel enkele overkoepelende inzichten over derdenschade gebracht, op basis waarvan, tentatief aan bepaalde ontwikkelingen betekenis kan worden gegeven.

\subsection{1 'Hulpperspectief': steeds verhaalsmogelijkheden voor hulpverstrekkers}

Over de gehele linie kwamen we verhaalsmogelijkheden tegen die door het 'hulpperspectief' zijn ingegeven: de verhaalsmogelijkheden van derden geven blijk van een visie op derden als 'hulpverstrekkers': als 'risicodragers', 'mantelzorgers' of 'geldschieters' van de primair benadeelde. Die visie staat haaks op de visie op derden als zelfstandig benadeelden, die 'eigen' schade lijden die niet samenvalt met de belangen van de primair benadeelde. Derdenschade dus, die wel het gevolg is van de schade van de primair benadeelde, maar die daar geen fotokopie van is. We zagen dat derden op alle deelterreinen recht hebben op verhaal voor 'kopieschade': schade die, zonder de aanwezigheid van derden, voor rekening zou zijn gekomen van de primair benadeelde.

Dit geldt in de eerste plaats voor schuldenaren, die om zakelijke redenen schaderisico's op zich nemen, zoals schadeverzekeraars. Met betrekking tot de verhaalsmogelijkheden lieten de deelterreinen over de gehele linie een uitbreiding van de aansprakelijkheid van de schadeveroorzaker zien in het voordeel van deze derden. ${ }^{182}$

I8o Par. I.2.

I8I Par. I.3.

I82 Par. 3.2.I, par. 3.3.2, par. 3.3.10 en par. 3.4.9. 
We zagen dit het duidelijkst bij personenschade en bij zaakschade van de primair benadeelde. Het gemeenschappelijke punt is dan dat deze derden de verplichting voldoen die primair op de aansprakelijke rust. Het gaat kortom om het aspect van het - verschuldigd of onverschuldigd - op zich nemen van de schuld van de aansprakelijke. Die moet, in zijn verhouding tot de primair benadeelde, de schade dragen en mag daar ook door de tussenkomst van derden niet aan ontkomen.

Maar verdedigd werd dat deze visie op derden (als 'hulpverstrekkers' en dus niet zozeer zelfstandig benadeelden) in zekere zin ook kan worden teruggevonden in de uitbreiding van de aansprakelijkheid naar afgeleide schade ingevolge de arresten Kip en Sloetjes v. Rabobank en Kessock v. SFT Bank. ${ }^{\mathrm{I} 33}$ Die betreffen gevallen waarin aandeelhouders ook schade lijden als borg en kredietverstrekker, ten gevolge van de benadeling van de vennootschap. In die hoedanigheid zijn deze aandeelhouders, al dan niet uit eigen belang, financieel voor de vennootschap 'in de bres gesprongen': bijvoorbeeld door persoonlijke betrekkingen aan te gaan en uit hun privévermogen vennootschapsschulden af te lossen. ${ }^{184}$

Deze uitbreiding van aansprakelijkheid vindt zijn grondslag niet in het verplichte karakter van de betaling of de rechtsplicht van de derde, maar in het belang van de primair benadeelde dat door de derden wordt gediend. Zij geldt vrij algemeen óók voor schadedragers die onverplicht en/of in natura optreden (schadeverzekeraars, naasten) en óók als ze uit (zakelijk) eigenbelang optreden (schadeverzekeraars, werkgevers, Kip en Sloetjes v. Rabobank). Ook zagen we deze uitbreiding van de aansprakelijkheid naar deze derden in gevallen waarin zij voor hun 'hulp' een tegenprestatie ontvangen van de primair benadeelde (of eventueel derden). Denk aan de aanspraak op premiebetaling (zoals over het algemeen het geval is voor schadeverzekeraars en sociale verzekeraars) en het recht op terugbetaling van een in privé gegeven geldlening (Kip en Sloetjes $v$. Rabobank).

\subsubsection{Twee verschilpunten bij verhaalsrechten voor 'hulpverstrekkers'}

Wel zijn er ook twee belangrijke verschilpunten. Het eerste betreft de omvang van de verhaalsmogelijkheden van deze 'hulpverstrekkers': alleen voor derden die letselschade voor hun rekening nemen zijn de verhaalsmogelijkheden van deze derden beperkt tot schade die oorspronkelijk, zonder de tussenkomst van de derde, schade is van de primair benadeelde (ziektekosten, reparatiekosten, enzovoort). Aandeelhouder Kip bijvoorbeeld had voorts recht op vergoeding van zijn eigen immateriële schade en ook bij zaakschade staat in beginsel niets aan de vergoeding van bijkomende zelfstandige eigen schade in de weg. ${ }^{185}$ Zijn positie had echter ook meer weg van 'primair benadeelde' dan van derde. ${ }^{86}$

Het tweede verschilpunt betreft de vraag aan wie de vordering op de schadeveroorzaker ter zake van deze 'hulpschade' precies toekomt (en of er daarbij sprake

I83 Par. 3.4.6.

I84 Par. 3.4.Io.

I85 Par. 3.4.6.

I86 Par. 3.4.9. 
is van een zekere rangorde of voorrang tussen de vorderingen van de primair benadeelde en derden geldt of zou moeten gelden). Bij zaakschade ligt het primaat voor het instellen van de vordering bij de primair benadeelde. Bij personenschade is er een wat minder eenduidig beeld: de vordering komt aan 'hulpverstrekkers' zelf toe (sociale risicodragers, schadeverzekeraars, ${ }^{187}$ naasten, enzovoort), maar mag dan niet in het nadeel van de primair benadeelde worden uitgeoefend. ${ }^{188}$

\subsection{3 'Risicoperspectief': waarom hier geen uitbreiding van aansprakelijkheid?}

Ook kwamen we her en der het 'risicoperspectief' tegen: indien derden in hun verhouding tot de primair benadeelde schuldeiser of aandeelhouder zijn, die gerechtigd zijn tot contractuele prestaties of ander voordeel (bijvoorbeeld dividenduitkeringen) met betrekking tot de persoon (denk aan de werkgever die een moeilijk vervangbare werknemer verliest of het operahuis dat voorstellingen moet afgelasten wegens het letsel of overlijden van een grote artiest), bepaalde zaken (afnemers of leveranciers) of het vermogen van de primair benadeelde (schuldeisers aandeelhouders), dan komt het risico van de aantasting voor hun eigen rekening. Ze zijn dit zuiver financiële risico voorafgaand aan het schadevoorval aangegaan en hebben in beginsel geen recht op schadevergoeding. De terughoudendheid zit echter niet zozeer bij het feit dat er schade wordt geleden in een zuiver financieel belang, maar dat er schade wordt geleden in een belang dat niet is te herleiden tot de schade die, zonder tussenkomst van de derde, de primair benadeelde ten beurt zou zijn gevallen. Bij 'afgeleide schade' van aandeelhouders kan men zeggen dat ze bewust het risico aangaan om hun eigen (privé)geld te steken in een organisatie met een afgescheiden vermogen.

Maar voor al deze gevallen blijft het risicodenken onbevredigend: dat de derde risico's is aangegaan zegt misschien iets over de calculeerbaarheid daarvan, maar waarom zou het niet beschermd worden? Ik zou dan ook zeker niet zo ver willen gaan dat het feit dat de derde het risico vooraf is aangegaan meebrengt dat hij geen verhaalsmogelijkheden heeft (want dat kunnen we dan net zo goed zeggen voor schadeverzekeraars of andere 'hulpverstrekkers'). Ik zoek de verklaring liever in het ontbreken van het 'hulpbelang': de schade die deze derden lijden, houdt geen verband met vormen van hulpverlening aan de primair benadeelde. Juist die hulpverlening maakt het verband met de vorige schakel (en dus met de verplichting van de schadeveroorzaker) zo sterk. Dat argument ontbreekt bij de genoemde risicogevallen (de 'afgeleide schade' van aandeelhouders, contractsschade als gevolg van personen- of zaakschade). Deze laatste gevallen hebben echter hoofdzakelijk betrekking op contractuele schade en bedrijfsrisico's; die moet men dan dus kennelijk contractueel ondervangen, bijvoorbeeld via stipulaties in de (contractuele) verhouding tot de primair benadeelde, door het afsluiten van een verzekering, of via doorberekening in de prijzen van producten en diensten.

I87 Met de kanttekening dat schadeverzekeraars door subrogatie in de vordering van de primair benadeelde treden.

I88 Althans dit wordt voor de 'zakelijke' derden aangenomen (schadeverzekeraars en sociale risicodragers), die daar soms ook speciale codes voor hebben, zie Engelhard 2003, p. 370 e.v. 


\subsubsection{Overige gevallen}

Het zou te ver voeren om te concluderen dat derdenschade onder het Nederlandse recht alleen vergoed wordt wanneer het om schade gaat die, zonder tussenkomst van de derde, voor rekening zou zijn gekomen van de primair benadeelde. Of dat derdenschade van anderen dan 'hulpverstrekkers' niet wordt vergoed. Ik noem twee categorieën van gevallen die eigenlijk moeilijk bij elk van beide perspectieven zijn thuis te brengen, maar er zijn ongetwijfeld nog diverse andere, meer specifieke gevallen.

Het eerste type gevallen betreft derdenschade door gebruiksderving. Zo zagen we ruime verhaalsmogelijkheden voor hulpdiensten die tijdelijk hun materieel niet kunnen inzetten, afnemers of gebruikers van transportkabels (gasleidingen e.d.) en voor derden met feitelijke macht over een zaak die aan de primair benadeelde toebehoort. Indien de derde ten tijde van het schadevoorval een gebruiksrecht had met betrekking tot de zaak die aan de primair benadeelde toebehoort, kortom: gebruiksgerechtigde is, dan heeft hij wél recht op verhaal indien dat gebruiksrecht door de schadeveroorzaker op onrechtmatige wijze wordt gefrustreerd.

Het tweede type gevallen betreft schuldeisers die een waardevermindering ondervinden van de benadeling van het vennootschapsvermogen of wier schade bestaat uit het niet kunnen executeren van een veroordelend vonnis tot een door de vennootschap aan hem verschuldigde geldsom. Zij hebben in zoverre wel recht op schadevergoeding, zij het dan dat er, indien bij faillissement ook de curator collectief een vordering tegen de aansprakelijke instelt, sprake is van een 'praktische processuele voorrangsregel' ten behoeve van de curator.

\subsection{Tot slot}

Een algemeen punt dat in de analyse telkens terugkwam is dat het onderscheid tussen 'primair benadeelde' en 'derden' en de begrippen 'afgeleide schade', maar ook 'derdenschade' zelf moeilijk hanteerbaar zijn als juridische criteria voor de afbakening van aansprakelijkheid. Men kan daar volgens mij dan ook beter geen 'harde' rechtsgevolgen aan verbinden. Derdenschade, het in feite door twee sequentiële oorzaken veroorzaakt zijn van de schade, heeft betekenis omdat het een zeker spanningsveld laat zien tussen vergoeden en/of beperken van de schade, maar het moet niet als een technisch criterium worden gehanteerd. Ingewikkelde vragen zoals de vraag naar de exacte mate waarin de schade van aandeelhouders is 'afgeleid' van de vermindering van het vennootschapsvermogen of de vraag naar de (klinisch niet vast te stellen) scheidslijn tussen shock- en affectieschade, moeten de schadepraktijk bespaard blijven. De categorische uitsluiting van de derdenschade bij aandeelhouders en personenschade staat bovendien onder druk en leidt tot ingewikkelde oplossingen, die soms moeilijk in het systeem zijn te passen (denk aan de relativiteitsnorm van het Taxibus-arrest).

Het laatste punt dat over de gehele linie opvallend was, betreft het onderscheid tussen de vraag of derdenschade voor vergoeding in aanmerking komt en de vraag aan 
wie in dat geval het vorderingsrecht toekomt: de primair benadeelde en/of aan de derde. Dit onderscheid loopt bij de discussies over derdenschade op verscheidene deelterreinen door elkaar. Dat is van belang: het maakt met name bij zaakschade wel degelijk verschil of men vindt dat de gebruiksderving van degene met feitelijke macht, maar geen absolute macht over een zaak, niet voor vergoeding in aanmerking komt, of dat men slechts moeite heeft met vorderingen van deze derden indien ze het belang van de eigenaar frustreren. ${ }^{189}$ Dit is een punt dat in toekomstige studies wellicht aandacht verdient.

I89 Zie par. $3 \cdot 3 \cdot 3$ en par. $3 \cdot 3 \cdot 4$. 